\title{
DOUTRINA BRASILEIRA E A ORDEM PÚBLICA PROCESSUAL, ESSA DESCONHECIDA ${ }^{1}$
}

\section{THE BRAZILIAN DOCTRINE AND THE PROCEDURAL PUBLIC ORDER, THIS UNKNOWN ONE}

Márcio Oliveira Rocha Doutor em Direito (UFPE). Mestre em Direito (UFAL). Professor Titular I (UNIT/AL). Professor Efetivo (UNEAL). Membro da ANNEP. Membro da ABDPro. Advogado. Líder do Grupo de Pesquisa: Teoria do Direito e Processo Contemporâneo. $^{2} \quad$ Maceió/AL. E-mail: marcio.rocha@uneal.edu.br

RESUMO: O presente artigo tem o escopo de contrapor estudos específicos sobre o tema, os quais vêm direcionando à compreensão da ordem pública no âmbito do processo civil brasileiro. Outrossim, provocar um diálogo para que possamos estabelecer uma releitura contemporânea do termo e fomentar sua discussão. Para isso, buscamos analisar três teses desenvolvidas em programas de doutoramento, passando a imprimir uma metodologia dialética e qualitativa, com fins propositivos.

PALAVRAS-CHAVE: Teoria do Direito. Processo Civil. Ordem Pública Processual.

ABSTRACT: The present article has the scope of opposing specific studies on the subject, which have been heading the understanding of the public order in the sphere of the Brazilian Civil Process. Furthermore, its aim is to provoke a dialogue so that we can establish a contemporary re-reading of the term and encourage its discussion. For this, we seek to

\footnotetext{
${ }^{1}$ Artigo recebido em 29/05/2019 e aprovado em 23/07/2019.

2 <dgp.cnpq.br/dgp/espelhogrupo/1588147618373208>
} 
Revista Eletrônica de Direito Processual - REDP.

Rio de Janeiro. Ano 13. Volume 20. Número 2. Maio a Agosto de 2019

Periódico Quadrimestral da Pós-Graduação Stricto Sensu em Direito Processual da UERJ

Patrono: José Carlos Barbosa Moreira (in mem.). ISSN 1982-7636. pp. 267-312

www.redp.uerj.br

analyse three theses developed in doctoral programs, starting to print a dialectical and qualitative methodology, with propositional objective.

KEYWORDS: Theory of law. Civil Procedure. Procedural Public Order.

SUMÁRIO: Introdução. 1. Ordem Pública e Processo: Ricardo de Carvalho Aprigliano. 2. Proposta de sistematização das questões de ordem pública processual e substancial: Gisele Santos Fernandes Góes. 3. Ordem Pública Processual: Trícia Navarro Xavier Cabral. 4. A insuficiência do parâmetro da ordem pública: Antonio do Passo Cabral. 5. Considerações finais: Será a ordem pública processual uma situação de "tû-tû"? Referências.

\section{INTRODUÇÃO}

A ordem pública, como outros fenômenos de conteúdo vago e indeterminado interesse público, justiça, liberdade, função social, boa-fé etc. -, ainda é motivo de muitas inquietações para dogmática jurídica.

Não raro, nos deparamos, no desenvolvimento da vida profissional e acadêmica, com expressões que muito mais transpassam uma percepção ${ }^{3}$ ou um sentimento, do que seu próprio conceito com definições lógicas e sistematizadas. Nesse sentido, a própria discussão do que é o Direito, desde o seu início até a atualidade, foi tomada de inúmeras teorias e teses no intuito de aclarar, muitas vezes, a sua percepção. E, ainda hoje, há quem questione o conteúdo do termo e a sua cientificidade, o que, ao nosso entender, mostra-se salutar.

Parece que o mesmo caminhar vem tomando a percepção de ordem pública. Essa junção emblemática de duas palavras com variadas significações e que, por vezes, também pode ser utilizada como argumentação retórica de justificação do exercício de poder, vem ocasionando relevantes discussões em vários ramos do Direito. Por isso, no atual momento histórico-dogmático, ganha relevância a sua discussão nos bancos das academias jurídicas.

Em sua história, a ordem pública aparece como forma de blindagem da coisa pública dos Romanos, como um dos corolários da seguinte passagem do Digesto de Justiniano:

\footnotetext{
${ }^{3}$ Percepção no sentido de ter a capacidade de sentir.
} 
Revista Eletrônica de Direito Processual - REDP.

Rio de Janeiro. Ano 13. Volume 20. Número 2. Maio a Agosto de 2019

Periódico Quadrimestral da Pós-Graduação Stricto Sensu em Direito Processual da UERJ

Patrono: José Carlos Barbosa Moreira (in mem.). ISSN 1982-7636. pp. 267-312

www.redp.uerj.br

privatorum conventio juri publico non derogat. O que acabou por influenciar vários sistemas jurídicos, principalmente após a inserção deste sentimento no Código Civil francês, em 1804, (art. $6^{\circ}$, on ne peut déroger, par des conventions particulières, aux lois qui intéressent l'ordre public et les bonnes moeurs), refletindo em legislações de matriz romana, como o nosso Código Civil (art. 2.035, parágrafo único, nenhuma convenção prevalecerá se contrariar preceitos de ordem pública).

Assim, a percepção de ordem pública já nasce com ares de autoridade e de blindagem das coisas do Estado, marcado pelo elevado grau de interesse público, como forma de controle do exercício das liberdades dos indivíduos. Nesse ponto, estabelece-se a clássica dicotomia do público versus privado ou da ordem pública versus ordem privada. De igual modo, no Direito Internacional Privado, a ordem pública passou a blindar a aplicação da legislação estrangeira, no sentido de impor a soberania estatal, desmembrando a ordem pública em interna e internacional.

Por essa razão, a doutrina, de um modo geral, começou a associar a percepção de ordem pública à maioria das normas jurídicas que não possuíam em seu suporte fático o elemento vontade e, ao mesmo tempo, limitavam a liberdade dos indivíduos, denominandoas de normas cogentes, porque geram situações jurídicas que limitam o autorregramento da vontade. Ao passo que surge a dicotomia norma cogente versus norma dispositiva.

Existem, na doutrina brasileira, escritos direcionados à compreensão da ordem pública no âmbito processual civil, os quais tiveram como escopo delimitar a sua compreensão e até mesmo rechaçar a sua utilidade, como veremos. Por esta razão, o caminhar da ordem pública na doutrina processual civil brasileira se faz imprescindível para que possamos estabelecer a sua releitura dogmática contemporânea.

Desta forma, analisaremos as teses de doutoramento de Ricardo de Carvalho Aprigliano, Gisele Santos Fernandes Góes e Trícia Navarro Xavier Cabral.

\section{Ordem Pública e Processo: Ricardo de Carvalho Aprigliano}

O estudo de Ricardo de Carvalho Aprigliano, ${ }^{4}$ como bandeirante a publicar livro específico sobre o tema no processo civil brasileiro, tem a fundamental importância de servir

\footnotetext{
${ }^{4}$ APRIGLiano, Ricardo de Carvalho. Ordem Pública e Processo: o tratamento das questões de ordem pública no direito processual civil. São Paulo: Atlas, 2011.
} 
Revista Eletrônica de Direito Processual - REDP.

Rio de Janeiro. Ano 13. Volume 20. Número 2. Maio a Agosto de 2019

Periódico Quadrimestral da Pós-Graduação Stricto Sensu em Direito Processual da UERJ

Patrono: José Carlos Barbosa Moreira (in mem.). ISSN 1982-7636. pp. 267-312

www.redp.uerj.br

de base e orientação dogmática para todas as demais pesquisas sobre o assunto. Por isso, iniciamos com a sua análise, em que pese haja um denso estudo realizado anteriormente com este mesmo direcionamento, por Gisele Santos Fernandes Góes, porém não conhecemos a publicação de livro, mas será analisado logo em seguida.

A obra de Ricardo Aprigliano tem como objetivo sistematizar a ordem pública no direito processual, inclusive inova tentando estabelecer uma proposta de seu conceito no âmbito processual, o que enaltece a marca de uma forma de "revolução científica". 5 Assim, por sua densidade e qualidade técnica, a obra se mostra como marco dogmático de análises sobre o tema, como forma de manter acesa a discussão e as sementes que o autor amanhou.

Como forma de objetivar a análise do estudo de Ricardo Aprigliano, apreciaremos, a princípio, alguns pontos que entendemos dissonantes com o nosso entendimento, porém são relevantes para o diálogo com o trabalho, quais sejam: a) a ordem pública aliada aos contornos do interesse público; b) o conceito de ordem pública estabelecido pelo autor; c) a ordem pública como controle tempestivo da regularidade processual; e, d) a ordem pública como norma de direito positivo. Após este exame, apontaremos os pontos que convergem com nosso entendimento.

Quanto ao primeiro quesito, ao apreciar suas razões teóricas, chegamos ao apontamento de que a ordem pública, em que pese se origine da noção de interesse público e Direito Público, ainda que se tente desmembrá-la destas noções, não encontra tanta sustentação dogmática a justificar situações de indisponibilidade, como defende o autor. Senão vejamos.

Neste ponto, Aprigliano defende que o interesse público está na base da noção de ordem pública no âmbito processual, ${ }^{6}$ o que acaba por confundir um pouco e, de certa forma, unir as duas expressões.

Assim, em se admitindo tal concepção, despiciendo a utilização da expressão ordem pública processual como instrumento de controle de uma atividade jurisdicional efetiva,

\footnotetext{
${ }^{5}$ KUHN, Thomas S. A estrutura das revoluções científicas. trad. Beatriz Vianna Boeira e Nelson Boeira. $12^{\mathrm{a}}$ ed. São Paulo: Perspectiva, 2013, p. 201.

6 "Em conclusão, pode-se afirmar que o interesse público que informa e se encontra na base da ordem pública significa, em relação ao plano do direito processual, que a atividade jurisdicional deve ser realizada visando a obtenção do resultado mais efetivo, justo, e tempestivo da crise de direito material trazida a julgamento" (APRIGliAnO, Ricardo de Carvalho. Ordem Pública e Processo: o tratamento das questões de ordem pública no direito processual civil. São Paulo: Atlas, 2011, p. 68).
} 
Revista Eletrônica de Direito Processual - REDP.

Rio de Janeiro. Ano 13. Volume 20. Número 2. Maio a Agosto de 2019

Periódico Quadrimestral da Pós-Graduação Stricto Sensu em Direito Processual da UERJ

Patrono: José Carlos Barbosa Moreira (in mem.). ISSN 1982-7636. pp. 267-312

www.redp.uerj.br

justa e tempestiva, bastando, a simples aplicação da ideia de interesse público processual, que o próprio autor descreve em sua obra. ${ }^{7}$

Por isso, tentamos defender uma independência da noção de ordem pública da ideia de interesse público, ou seja, a compreensão do que se entende por ordem pública não deveria depender e não deveria sempre estar ligada ao interesse público. Pois, ao utilizar as expressões com o mesmo significado, acabamos por sufocar os conteúdos dos dois seguimentos jurídicos, sem os distinguirmos de uma maneira clara e, minimamente, objetiva.

Assim, se dissermos que a ordem pública e o interesse público andam sempre entrelaçados, como verdadeiros irmãos siameses, não poderemos identificar e, muito menos, justificar a distinção de seus conteúdos, quiçá constatarmos uma individualização ou categorização dogmática. Em que pese estes fenômenos jurídicos possuam lugares comuns.

Percebe-se que a ordem pública é uma espécie de corolário do Direito Público e do interesse público, ${ }^{8}$ em contraponto ao interesse individual e à autonomia da vontade (ordem privada), o que conturba muito sua compreensão, deixando-a muito mais volátil, como um verdadeiro argumento para justificar o controle estatal na atuação dos indivíduos, o que é bastante defendido pelos defensores da metodologia da instrumentalidade do processo.

Contudo, mesmo que se questione a natureza da ordem pública associada ao Direito Público e interesse público, a fixação de sua estruturação dogmática contemporânea se faz imprescindível, justamente para contrapor determinados questionamentos quanto à utilidade dessa compreensão no ordenamento jurídico.

Assim, da mesma forma que a dicotomia público e privado tem sua utilidade, a forma de percepção da situação de ordem pública ou o que cerca esse misterioso encontro de palavras (ordem + pública) é de grande relevância para o estudo do direito contemporâneo. Outrossim, para o Direito Processual Civil, porquanto, "apesar dessa absoluta falta de explicitação conceitual, não é arriscado afirmar que, paradoxalmente, não é possível

\footnotetext{
7 “[...] o interesse público deve ser associado aos objetivos que o Estado-juiz procura alcançar por meio da atividade jurisdicional, os quais guardam direta relação com a oferta de meios para o acesso à justiça e com a obtenção de resultados efetivos quanto à crise de direito material trazida, eliminando conflitos mediante critérios justos" (APRIGLIANO, Ricardo de Carvalho. Ordem Pública e Processo: o tratamento das questões de ordem pública no direito processual civil. São Paulo: Atlas, 2011, p. 67-68).

8 "Por ser identificável com as noções de bem comum, interesse geral ou social, ou interesse de todo povo, a ordem pública era necessariamente concebida como parte do Direito Público. A 'ordem privada', pelo contrário, diz respeito exclusivamente ao interesse particular e relativo aos indivíduos, esfera que ficava fora de qualquer classe de imperatividade derivada de normas jurídicas" (ARIGÓN, Mario Garmendia. Ordem Pública e Direito do Trabalho. Trad. Edilson Alkmim Cunha. São Paulo: LTr, 2003, p. 22).
} 
Revista Eletrônica de Direito Processual - REDP.

Rio de Janeiro. Ano 13. Volume 20. Número 2. Maio a Agosto de 2019

Periódico Quadrimestral da Pós-Graduação Stricto Sensu em Direito Processual da UERJ

Patrono: José Carlos Barbosa Moreira (in mem.). ISSN 1982-7636. pp. 267-312

www.redp.uerj.br

conceber algum ordenamento positivo no qual a ideia de ordem pública não esteja presente". 9

Deste modo, podemos constatar que, pelo fato de sua gênese advir das noções de Direito Público e interesse público, ela é muito utilizada como sinônimo dessas expressões, como uma forma de imprimir um ar de autoridade aos comandos e normas estabelecidas pelo Poder Público, marca registrada da própria reformulação do Direito Público europeu, pós Revolução Francesa. ${ }^{10}$

Ademais, nesse ponto, a ordem pública surge para atribuir uma carga imperativa ao Direito Público, no sentido de fortalecer a ideia do poder soberano do Estado, mostrando-se uma forma de justificação do poder estatal em determinado território, impondo aos indivíduos a vontade soberana e inquestionável de seu poder. ${ }^{11}$

Desta forma, a princípio, parece-nos que deslocar e analisar de uma forma autônoma o conteúdo de ordem pública, quebrando esse paradigma de ligação com o interesse público e o Direito Público, mostra-se necessário para experimentar se realmente essa compreensão possui vida própria e se é autossuficiente ou, realmente, não tem sentido ou utilidade a sua permanência no direito processual civil contemporâneo.

Porquanto, observamos que a sua função não deve ser somente de limitação da autonomia da vontade ou das partes em um processo, mas também de quem detém o próprio

\footnotetext{
${ }^{9}$ ARIGÓN, Mario Garmendia. Ordem Pública e Direito do Trabalho. Trad. Edilson Alkmim Cunha. São Paulo: LTr, 2003, p. 27.

10 "Es la idea capital del gobierno por la Ley o del règne de la Loi, expresión capital, que veremos aparecer tempranamente entre los conceptos revolucionarios. Esa idea está ya explícitamente en la Declaración de 1789. Vimos en el capítulo precedente que el artículo 4 había aportado la idea esencial de la Ley como límite de las libertades, como la técnica para asegurar la concurrencia y la coexistencia recíproca de las liberdades de todos los ciudadanos. Pero la Declaración contiene otros cuatro artículos capitales para definir el papel esencial que se reserva a la Ley en la construcción política, los artículos 5, 6, 7 y 8. [...] En estos cuatro prodigiosos artículos (unidos al art. $4^{\circ}$, ya comentado más atrás) se encierra una idea esencial, la de la legalización general del ejercicio del poder, la idea de la que va a surgir, justamente, todo el nuevo Derecho Público europeo ulterior" (ENTERRÍA, Eduardo García de. La lengua de los derechos. La formación del Derecho Público europeo tras la Revolución Francesa. Madrid: Real Academia Española, 1994, p. 123-124).

11 "Faz parte da essência do Estado que seja soberano, o maior poder sobre o seu território, não tolerando aí poder algum acima dele nem a seu lado. Desse ponte de vista, o Estado de Cortes se afigura, contudo, como uma duplicidade de Estados entrelaçados: de um lado o senhor feudal, soberano irrestrito apenas em seu domínio; de outro lado, as Cortes com soberania quase tão irrestrita sobre os pequenos proprietários, cobrandolhes impostos, julgando-os, chamando-os às armas; reunindo-se em assembleias sem serem convocadas e negociando com o senhor feudal em pé de igualdade, a ele se submetendo apenas à medida que se tenham submetido espontaneamente, atendendo ao chamado às armas por contrato de vassalagem, comprometendo-se a apoio financeiro através de tributos por ele solicitados; provavelmente tratando com potências estrangeiras através de enviados próprios, contrariando a política do senhor feudal. A dupla soberania anárquica do Estado de Cortes conduziu obrigatoriamente a uma luta constante pela soberania única;" (RADBRUCH, Gustav. Introdução à ciência do direito. trad. Vera Barkow. $2^{\mathrm{a}}$ ed. São Paulo: WMF Martins Fontes, 2010, p. 38).
} 
Revista Eletrônica de Direito Processual - REDP.

Rio de Janeiro. Ano 13. Volume 20. Número 2. Maio a Agosto de 2019

Periódico Quadrimestral da Pós-Graduação Stricto Sensu em Direito Processual da UERJ

Patrono: José Carlos Barbosa Moreira (in mem.). ISSN 1982-7636. pp. 267-312

www.redp.uerj.br

poder público. Contudo, em que pese possuir um caráter imperativo, ao nosso sentir não são absolutas e não se ligam exclusivamente ao interesse público, como assevera a metodologia da instrumentalidade do processo, defendida por Cândido Rangel Dinamarco. ${ }^{12}$

Revela-se um tanto questionável, do ponto de vista dogmático e pragmático, a assertiva de que a noção de interesse público abarcaria a aplicação de determinadas situações ditas de ordem pública, ou que estas teriam essa designação pelo fato de tutelarem o interesse público. De sorte que bastaria a noção de interesse público para discutir a questão e pôr um fim nas incansáveis elucubrações dogmáticas sobre o tema da ordem pública.

Até porque, em certa medida, podemos afirmar que a norma jurídica tem o ideal de produzir situações que atinjam uma coletividade, ainda que não se conheça seu texto, ${ }^{13}$ podendo suscitar, neste aspecto, os interesses público e coletivo das normas jurídicas, o que confunde e dificulta ainda mais a noção específica do termo ordem pública ligada ao interesse público.

Assim, para justificar o sentimento da ordem pública, devemos, primeiramente, verificar se há uma autonomia e independência, para que possamos estruturá-la em nosso ordenamento jurídico processual civil. Depois, identificar seus contornos e utilidade ao sistema, sendo esta uma das tarefas a serem desenvolvidas por futuros estudos.

Por fim, destacar a compreensão de ordem pública do Direito Público e do interesse público, não significa negar a existência de "lugares comuns"14 que estes seguimentos possam ter, o que não impede esse corte epistemológico que estamos propondo. Desse modo,

\footnotetext{
12 "São de ordem pública todas as normas (processuais ou substanciais) referentes a relações que transcendam a esfera de interesses dos sujeitos privados, disciplinando relações que os envolvam mas fazendo-o com atenção ao interesse da sociedade como um todo, ou ao interesse público. [...] Esses diferentes graus de imperatividade indicam a existência de normas processuais cogentes, ao lado de normas processuais dispositivas - aquelas, com imperatividade absoluta e nenhuma liberdade deixada às partes para disporem de modo diferente, ainda que de acordo; estas, dotadas de imperatividade relativa e portanto portadoras de preceitos suscetíveis de serem alterados pelos litigantes." (DINAMARCO, Cândido Rangel. Instituições de Direito Processual Civil. Vol. I. $8^{\text {a }}$ ed. rev. e atual. São Paulo: Malheiros, 2016, p. 137-139).

13 “Art. 3o. Ninguém se escusa de cumprir a lei, alegando que não a conhece." (Decreto-Lei n. ${ }^{\circ}$ 4.657/42 - Lei de Introdução às normas do Direito Brasileiro)

14 "Portanto, os lugares-comuns se caracterizavam, primitivamente, por sua imensa generalidade, que os tornava utilizáveis em todas as circunstâncias. [...] Os lugares-comuns de nossos dias se caracterizam por uma banalidade que não exclui de modo algum a especificidade. Tais lugares-comuns não são, a bem dizer, senão uma aplicação dos lugares-comuns, no sentido aristotélico, a temas particulares. Mas, como essa aplicação é feita a um tema tratado com frequência, que se desenvolve numa certa ordem, com conexões previstas entre lugares, agora só se pensa em sua banalidade, ignorando-lhes o valor argumentativo. Isso a tal ponto, que se tende a esquecer que os lugares formam um arsenal indispensável, do qual, de um modo ou de outro, quem quer persuadir outrem deverá lançar mão.” (PERELMAN, Chaïm. Tratado da Argumentação: a nova retórica. trad. Maria Ermantina de Almeida Prado Galvão. $3^{\mathrm{a}}$ ed. São Paulo: Editora WMF Martins Fontes, 2014, p. 94-95).
} 
Revista Eletrônica de Direito Processual - REDP.

Rio de Janeiro. Ano 13. Volume 20. Número 2. Maio a Agosto de 2019

Periódico Quadrimestral da Pós-Graduação Stricto Sensu em Direito Processual da UERJ

Patrono: José Carlos Barbosa Moreira (in mem.). ISSN 1982-7636. pp. 267-312

www.redp.uerj.br

em que pese a existência de "lugares comuns" entre a ordem pública e o interesse público, mesmo porque a expressão ordem pública advém da noção de Direito Público e interesse público, os seus lugares específicos devem ser identificados para melhor compreensão da ordem pública no momento contemporâneo, principalmente no âmbito do processo civil brasileiro.

Por estes motivos, dissentimos do autor quanto a este ponto, pois entendemos que a possível percepção de ordem pública no âmbito processual está mais liga ao conteúdo da segurança jurídica do processo, do que de um genuíno interesse público ou coletivo.

Outra questão relevante é o conceito de ordem pública processual estabelecido pelo autor que, ao tomar como base a noção de interesse público como conteúdo da ordem pública, ao nosso entender, acaba por unificar as expressões em uma extensa compreensão, senão vejamos:

Com base nestas considerações, a ordem pública processual pode ser definida como o conjunto de regras técnicas que o sistema concebe para o controle tempestivo da regularidade do processo, necessariamente voltadas para o objetivo maior de permitir que seus escopos sejam atingidos, com rapidez, economia e racionalidade, regras que devem ser suscitadas pelas partes ou pelo magistrado com obrigatória observância do contraditório, e que apenas excepcionalmente devem conduzir à extinção anômala do processo ou impedir que se realize o julgamento quanto ao mérito do litígio. ${ }^{15}$

Como podemos observar, esta definição muito se assemelha ao que o próprio autor definiu como sendo interesse público no âmbito processual.

Destarte, poderemos utilizar esta compreensão também para destacar a noção de interesse público no processo, onde assevera, com outras palavras, que o interesse público deve nortear a atividade jurisdicional como forma de garantir uma prestação jurídica efetiva, justa e tempestiva. ${ }^{16}$

O que, em nossa análise, acaba por confundir os conteúdos e não identifica com certa clareza o que é a ordem pública processual, uma vez que poderíamos dizer que toda norma

15 APRigliano, Ricardo de Carvalho. Ordem Pública e Processo: o tratamento das questões de ordem pública no direito processual civil. São Paulo: Atlas, 2011, p. 106.

${ }^{16}$ APRIGLIANO, Ricardo de Carvalho. Ordem Pública e Processo: o tratamento das questões de ordem pública no direito processual civil. São Paulo: Atlas, 2011, p. 68. 
Revista Eletrônica de Direito Processual - REDP.

Rio de Janeiro. Ano 13. Volume 20. Número 2. Maio a Agosto de 2019

Periódico Quadrimestral da Pós-Graduação Stricto Sensu em Direito Processual da UERJ

Patrono: José Carlos Barbosa Moreira (in mem.). ISSN 1982-7636. pp. 267-312

www.redp.uerj.br

(segundo o autor, regra jurídica) que tiver o escopo de controlar tempestivamente a atividade jurisdicional para uma prestação que se tenha uma decisão de mérito justa e efetiva, poderá ser considerada uma norma de ordem pública processual, o que, a princípio, em uma análise sumária, nos parece temerário.

Por exemplo, com base na compreensão estabelecida pelo autor, poderíamos dizer que o art. $4^{\circ}$ do CPC, o qual disciplina que "as partes têm o direito de obter em prazo razoável a solução integral do mérito, incluída a atividade satisfativa", seria uma norma de ordem pública processual. Pois, além de encontrar-se positivada, norteia e controla a atividade jurisdicional tendo como base o tempo (duração razoável do processo), enaltecendo a "primazia do exame do mérito"17 de maneira efetiva, em detrimento das questões eminentemente processuais ou formais.

Assim, em que pese a autenticidade da conceituação proposta pelo autor, esta não se mostra tão clara e, em certa medida, generaliza a compreensão da ordem pública no âmbito processual, pois pode ensejar variadas interpretações abrangentes, como a do exemplo acima descrito.

Outrossim, em certa medida, as normas jurídicas em geral, sejam processuais ou não, possuem como finalidade uma forma de garantir um controle e estabelecer uma regularidade no proceder das questões jurídicas, seja de conteúdo substancial ou procedimental.

Constatação esta que leva ao questionamento de que também não pode ser o controle tempestivo da regularidade do processo uma característica específica da ordem pública no processo civil, do contrário grande parte das normas jurídicas do nosso sistema jurídico seriam ditas de ordem pública, o que também não nos parece razoável.

Nas hipóteses de julgamento de improcedência liminar (art. 332, CPC), caso o magistrado não sentencie liminarmente a demanda, mesmo que o direito alegado na petição

\footnotetext{
17 “Além do princípio da duração razoável, pode-se construir do texto normativo também o princípio da primazia do julgamento de mérito, valendo dizer que as regras processuais que regem o processo civil brasileiro devem balizar-se pela preferência, pela precedência, pela prioridade, pelo primado da análise ou do julgamento do mérito. O juiz deve, sempre que possível, superar os vícios, estimulando, viabilizando e permitindo sua correção ou sanação, a fim de que possa efetivamente examinar o mérito e resolver o conflito posto pelas partes. O princípio da primazia do exame do mérito abrange a instrumentalidade das formas, estimulando a correção ou sanação de vícios, bem como o aproveitamento dos atos processuais, com a colaboração mútua das partes e do juiz para que se viabilize a apreciação do mérito." (CUNHA, Leonardo Carneiro da. In Comentários ao Código de Processo Civil. Organizadores: Lenio Luiz Streck, Dierle Nunes, Leonardo Carneiro da Cunha. São Paulo: Saraiva, 2016, p. 36).
} 
Revista Eletrônica de Direito Processual - REDP.

Rio de Janeiro. Ano 13. Volume 20. Número 2. Maio a Agosto de 2019

Periódico Quadrimestral da Pós-Graduação Stricto Sensu em Direito Processual da UERJ

Patrono: José Carlos Barbosa Moreira (in mem.). ISSN 1982-7636. pp. 267-312

www.redp.uerj.br

inicial contrarie enunciado de súmula do Supremo Tribunal Federal (art. 332, I, CPC), ${ }^{18}$ esta, segundo o conceito do autor, seria uma questão ordem pública processual. De sorte que, o magistrado deveria, tempestivamente, ao receber a petição inicial, adotar o referido procedimento.

Desta forma, indaga-se: o processo não teria o seu desenvolvimento regular caso siga com o tramite ordinário, com a citação do réu? Poderia o réu, após citado, alegar uma possível desnecessidade de citação por erro no procedimento e solicitar que o magistrado julgue com base no art. 332, por, supostamente, ser uma questão de ordem pública processual, a qual controle tempestivo da regularidade do processo?

São indagações que nos levam a refletir a extensão da compreensão de ordem pública processual estabelecida pelo autor. De sorte que acreditamos que nem todas as regras processuais que controlam tempestivamente a regularidade do processo e promovem as finalidades do exercício jurisdicional são dotadas desse caráter de ordem pública, em que pese, concordamos que estas regras processuais também possuam essa característica, porém, não de forma exclusiva.

O próprio autor reconhece que há dificuldade prática, por parte dos magistrados, ao analisarem no tempo idealizado (saneamento do processo) as questões que regularizam o processo, vindo a fazê-lo, muitas vezes, no momento de proferir a sentença, após a instrução e produção de provas, o que desnaturaria a característica de técnica tempestiva de regularidade processual. ${ }^{19}$

Ademais, vê-se que o próprio sistema processual admite julgamento de mérito em detrimento de determinadas normas processuais que possam gerar a nulidade do processo (art. 282, $\left.\S 2^{\circ}, \mathrm{CPC}\right),{ }^{20}$ como constatou o autor, ${ }^{21}$ inclusive defendendo a possibilidade de

\footnotetext{
18 “Art. 332. Nas causas que dispensem a fase instrutória, o juiz, independentemente da citação do réu, julgará liminarmente improcedente o pedido que contrariar: I - enunciado de súmula do Supremo Tribunal Federal ou do Superior Tribunal de Justiça;"

19 "Como resultado, a técnica de eliminar irregularidades nos momentos iniciais do processo deixa de ser aplicada, gerando diversas consequências que contrariam os próprios objetivos daquelas mesmas regras. Os juízes muitas vezes proferem julgamentos meramente processuais (sentenças terminativas), em momento do processo no qual toda a discussão do mérito e elementos de prova já estavam presentes." (APRIGLIANO, Ricardo de Carvalho. Ordem Pública e Processo: o tratamento das questões de ordem pública no direito processual civil. São Paulo: Atlas, 2011, p. 138).

20 “Art. 282. [...] § 2o Quando puder decidir o mérito a favor da parte a quem aproveite a decretação da nulidade, o juiz não a pronunciará nem mandará repetir o ato ou suprir-lhe a falta”.

21 “O que aqui se propõe é que raciocínio semelhante seja realizado também em relação às condições da ação e aos pressupostos processuais. Aliás, há base legislativa sólida para sustentar este argumento, na medida em que o Código expressamente dispõe que, 'quando puder decidir o mérito a favor da parte a quem aproveite a
} 
Revista Eletrônica de Direito Processual - REDP.

Rio de Janeiro. Ano 13. Volume 20. Número 2. Maio a Agosto de 2019

Periódico Quadrimestral da Pós-Graduação Stricto Sensu em Direito Processual da UERJ

Patrono: José Carlos Barbosa Moreira (in mem.). ISSN 1982-7636. pp. 267-312

www.redp.uerj.br

julgamento de mérito da demanda mesmo que haja uma questão de ordem pública processual pendente de análise, desde que o mérito seja julgado favorável a quem suscitou a referida questão. Porém, o autor não demonstra em quais casos ou como seria essa proposição na prática.

Contudo, não conseguimos vislumbrar a utilização do referido dispositivo para todas as questões nomeadas como de ordem pública no processo, como defende Ricardo Aprigliano, senão vejamos um exemplo.

Suscitada a incompetência absoluta do juízo, ou faltando à parte legitimidade extraordinária ou interesse processual, poderia ser julgado o mérito a seu favor, mesmo por um juízo absolutamente incompetente, sendo parte ilegítima ou lhe faltando interesse? Se adotarmos o entendimento literal do autor, a resposta seria positiva.

Contudo, ao nosso sentir, a proposição de uma forma tão extensa não se mostra salutar ao sistema, de sorte que se admitiria o julgamento de mérito por juízo absolutamente incompetente, ou se julgaria o mérito perante parte ilegítima ou sem interesse, o que desnaturaria a estabilidade, a coerência e a integridade do sistema processual, defendida pelo autor.

Apesar disso, comungamos em parte com a ideia do autor quanto à utilização do atual art. 282, $\S 2^{\circ}, \mathrm{CPC}$, não para todas as questões denominadas como de ordem pública no processo, mas para algumas questões que possam gerar até nulidade processual absoluta, desde que não traga prejuízo à segurança jurídica e desequilíbrio entre as partes.

Como, por exemplo, a ausência da intervenção do Ministério Público em ações que tenha que atuar como fiscal da ordem jurídica (art. 178, CPC). Ou seja, caso o Ministério Público não tenha participado de todo o processo de conhecimento em primeiro grau, e o incapaz suscite a nulidade absoluta do processo por este motivo, se o magistrado verificar que a ausência desta manifestação não traz prejuízo e o mérito a ser julgado por sentença é favorável ao incapaz, entendemos que há possibilidade de utilização do art. 282, §2 , CPC, como identificou Ricardo Aprigliano. ${ }^{22}$

declaração da nulidade, o juiz não a pronunciará nem mandará repetir o ato, ou suprir-lhe a falta (art. $\left.249, \S 2^{\circ}\right)$ '. Como acima afirmado, deve ser aplicado analogicamente este dispositivo legal tão relevante para todas as questões de ordem pública" (grifos aditados) (APRIGLIANO, Ricardo de Carvalho. Ordem Pública e Processo: o tratamento das questões de ordem pública no direito processual civil. São Paulo: Atlas, 2011, p. 99).

22 "O exemplo da intervenção obrigatória do Ministério Público é emblemático. No direito brasileiro, a nulidade do processo em que o Ministério Público não intervém é prevista em dois artigos do Código Civil (artigos 84 
Revista Eletrônica de Direito Processual - REDP.

Rio de Janeiro. Ano 13. Volume 20. Número 2. Maio a Agosto de 2019

Periódico Quadrimestral da Pós-Graduação Stricto Sensu em Direito Processual da UERJ

Patrono: José Carlos Barbosa Moreira (in mem.). ISSN 1982-7636. pp. 267-312

www.redp.uerj.br

Nos parece que nesse norte vem o Código de Processo Civil Português (2013), em seu

artigo 194. ${ }^{\circ},{ }^{\circ}$ " 1 , destaca que "a falta de vista ou exame ao Ministério Público, quando a lei exija a sua intervenção como parte acessória, considera-se sanada desde que a entidade a que devia prestar assistência tenha feito valer os seus direitos no processo por intermédio do seu representante". ${ }^{23}$

Ou seja, como no exemplo que suscitamos acima, caso o incapaz, tenha defendido os seus direitos pelo seu representante, não haveria a necessidade de declarar a nulidade processual. Mas, caso o incapaz não tenha exercido os seus direitos e suas garantias processuais, aí sim, haveria a necessidade de se declarar a nulidade, com a devida intervenção do Ministério Público, como descrito no artigo 194. ${ }^{\circ}, 2$, do Código de Processo Civil Português (2013). ${ }^{24}$

Talvez pela extensão do seu conceito, a sua definição de ordem pública processual deixou margens a várias interpretações e elucubrações, o que não tira o mérito, mas possibilita uma maior discussão e diálogo com suas ideias.

Outro ponto interessante do estudo de Ricardo Aprigliano é que as normas de ordem pública processuais são somente de direito positivo, ou seja, previamente estabelecidas pelo texto normativo, citando os requisitos da ação (legitimidade e interesse), os pressupostos processuais e as nulidades absolutas. ${ }^{25}$

Contudo, partindo da conceituação dada pelo autor, a criação das situações jurídicas para o caso concreto, no processo civil contemporâneo, ao nosso sentir não é somente estabelecida pelo direito positivo (legislador), mas também pelas próprias partes. Por exemplo, na fixação da competência arbitral através da cláusula arbitral.

As partes ao estabelecerem a competência do juízo arbitral no caso concreto, excluem a apreciação do mérito da demanda por parte do Poder Judiciário (incompetência absoluta), inclusive estabelecerão o procedimento instrutório que será adotado ao caso, os prazos e

e 246). Não obstante, há diversos julgados que desconsiderem tal nulidade, se a ausência do Parquet não causou prejuízo à parte que deveria ser tutelada por sua intervenção". (APRIGLIANO, Ricardo de Carvalho. Ordem Pública e Processo: o tratamento das questões de ordem pública no direito processual civil. São Paulo: Atlas, 2011, p. 90).

${ }^{23}$ PINTO, Rui Gonçalves. Notas ao Código de Processo Civil. $1^{\text {a }}$ Ed. Coimbra: Coimbra Editora, 2014, p. 130.

24 "2 - Se a causa tiver corrido à revelia da parte que devia ser assistida pelo Ministério Público, o processo é anulado a partir do momento em que devia ser dada vista ou facultado o exame." (PINTO, Rui Gonçalves. Notas ao Código de Processo Civil. Coimbra: Coimbra Editora, 2014, p. 130).

${ }^{25}$ APRIGlianO, Ricardo de Carvalho. Ordem Pública e Processo: o tratamento das questões de ordem pública no direito processual civil. São Paulo: Atlas, 2011, p. 119. 
Revista Eletrônica de Direito Processual - REDP.

Rio de Janeiro. Ano 13. Volume 20. Número 2. Maio a Agosto de 2019

Periódico Quadrimestral da Pós-Graduação Stricto Sensu em Direito Processual da UERJ

Patrono: José Carlos Barbosa Moreira (in mem.). ISSN 1982-7636. pp. 267-312

www.redp.uerj.br

como serão praticados os atos processuais, disposição normativa esta que também se enquadra no conceito estabelecido pelo autor, pois garante o controle tempestivo da atividade jurisdicional (juízo arbitral) para uma prestação do direito material no processo.

Em que pese a possibilidade da disposição das partes (convenção arbitral) advenha do direito positivo, a situação jurídica, propriamente dita, foi gerada por um negócio jurídico, e perfaz uma questão de conteúdo cogente, o que nos faz questionar as lições de Cândido Dinamarco, ao associar a noção de ordem pública a expressão da função pública e do poder estatal. $^{26}$

Portanto, tendo como premissa o conceito de ordem pública processual estabelecido por Ricardo Aprigliano, acreditamos que este ponto também merece uma reflexão. Pois, ainda que de se defenda que não há possibilidade das declarações de vontade produzam norma jurídica (imperativo despsicologizado), acreditamos que os negócios jurídicos podem gerar situações jurídicas, enquadrando-se inclusive, do ponto de vista pragmático, na própria compreensão dogmática de norma jurídica. ${ }^{27}$

Por isso, podemos afirmar que não só o ente estatal que produz situações jurídicas denominadas de cogentes, mas também as partes, o que nos leva a questionar a afirmação de Ricardo Aprigliano de que as normas de ordem pública processual somente se materializam pelo direito posto pelo Estado. Ou seja, previamente definidas pelo sistema, as quais as partes não poderiam utilizar o negócio jurídico (convenção arbitral) para estabelecer determinadas situações. $^{28}$

Mesmo que se admita renúncia ou convalidação da convenção arbitral (art. 337, §6 do (PC), ainda sim entendemos que ela não perde a sua característica inicial de

\footnotetext{
26 “Como critério geral, são de ordem pública as normas processuais destinadas a assegurar o correto exercício da jurisdição estatal (que é uma função pública, expressão do poder estatal), sem a atenção centrada de modo direito ou primário nos interesses das partes conflitantes." (DINAMARCO, Cândido Rangel. Instituições de Direito Processual Civil. Vol. I. $8^{a}$ ed. rev. e atual. São Paulo: Malheiros, 2016, p. 138).

27 '“[...] um diretivo vinculante, coercivo, no sentido de institucionalizado, bilateral, que estatui uma hipótese normativa (facti species) à qual imputa uma consequência jurídica (que pode ser ou não uma sanção), e que funciona como um critério para a tomada de decisão (decidibilidade)" (FERRAZ JUNIOR, Tercio Sampaio. Introdução ao Estudo do Direito: técnica, decisão, dominação. $8^{a}$ ed. São Paulo: Atlas, 2015, p. 92).

28 '“[...] a convenção de arbitragem ser ou não uma objeção processual não interfere na conclusão de que tal matéria não tem natureza de ordem pública, por diversos fatores. A despeito de ter sido eleita pelas partes, em autêntico negócio jurídico processual, é inegável que a via arbitral pode ser objeto de renúncia pelas partes, que poderão optar por litigar perante o Poder Judiciário. Tal aspecto de disponibilidade e de possibilidade de renúncia retira da convenção arbitral o elemento central da ordem pública, que é justamente a sua inderrogabilidade e impossibilidade de transação a ser respeito" (APRIGLIANO, Ricardo de Carvalho. Ordem Pública e Processo: o tratamento das questões de ordem pública no direito processual civil. São Paulo: Atlas, 2011, p. 130).
} 
Revista Eletrônica de Direito Processual - REDP.

Rio de Janeiro. Ano 13. Volume 20. Número 2. Maio a Agosto de 2019

Periódico Quadrimestral da Pós-Graduação Stricto Sensu em Direito Processual da UERJ

Patrono: José Carlos Barbosa Moreira (in mem.). ISSN 1982-7636. pp. 267-312

www.redp.uerj.br

imperatividade, pois, caso arguida, deve ser conhecida pelo juiz estatal, inclusive se o juízo arbitral reconhecer sua competência (art. 485, VII, do CPC).

Pois isso, entendemos que as situações jurídicas que se intitulam como de ordem pública processual permitem sim, em alguns casos, renúncia, preclusão, ${ }^{29}$ convalidação e negócio jurídico, ${ }^{30}$ o que também nos leva a questionar a necessidade de uma nova terminologia para a ordem pública processual, como forma de adequar ao momento dogmático contemporâneo. Sendo esta, também, mais uma proposição deste artigo.

Além disso, através da cláusula geral negocial do art. 190, do CPC ${ }^{31}$ é possível negociar normas processuais, partindo do mesmo pressuposto da arbitragem, remodelando situações denominadas de cogentes, estabelecendo novos ônus, poderes, faculdades e deveres processuais, nos processos que possuam discussão de direito material que admitam autocomposição.

Ademais, saliente-se que Ricardo Aprigliano admite que uma questão dita de ordem pública processual possa se convalidar, citando a perempção como exemplo. Senão vejamos.

Supõe o autor que, por alguma circunstância, não haja a alegação do instituto no processo (perempção), chegando-se ao resultado de mérito da demanda, o magistrado deveria fazer prevalecer a decisão de mérito. Afirmando ainda que, por ter um peso maior e pela finalidade de privilégio da análise do mérito, o magistrado ao invés de acolher a perempção e proferir um julgamento sem exame do mérito, manteria o julgamento de mérito, sob pena de desnaturar o escopo do sistema processual. ${ }^{32}$

\footnotetext{
${ }^{29}$ Uma das preclusões que sustentamos são quanto às questões já decididas, nesse ponto, concordamos com Fredie Didier, destacando que: "Não se permite que o tribunal, no momento do recurso, reveja questão que já fora anteriormente decidida, mesmo as processuais, e em relação à qual se operou a preclusão. O que se permite ao tribunal é conhecer, mesmo sem provocação, das questões relativas à admissibilidade do processo, respeitada, porém, a preclusão. Parece haver uma confusão entre a possibilidade de conhecimento ex officio de tais questões, fato indiscutível, com a possibilidade de decidir de novo questões já decididas, mesmo as que poderiam ter sido conhecidas de ofício." (DIDIER JR., Fredie. Pressupostos processuais e condições da ação: o juízo de admissibilidade do processo. $3^{\text {a }}$ tiragem. São Paulo: Saraiva, 2005, p. 87).

${ }^{30}$ DIDIER JR., Fredie. Fonte normativa da legitimação extraordinária no novo Código de Processo Civil: a legitimação extraordinária de origem negocial. Revista de Processo, vol. 232, jun., 2014, p. 73.

31 “Art. 190. Versando o processo sobre direitos que admitam autocomposição, é lícito às partes plenamente capazes estipular mudanças no procedimento para ajustá-lo às especificidades da causa e convencionar sobre os seus ônus, poderes, faculdades e deveres processuais, antes ou durante o processo.”

32 "Contudo, caso não se constate esta circunstância a tempo de evitar o desenvolvimento da quarta demanda, e caso ela chegue a ser julgada pelo mérito, é óbvio que a razão de ser da perempção perdeu sentido. Tudo o que se pretendia evitar não foi evitado. Assim, se a questão de ordem pública (perempção) tem um objetivo específico, e se o seu reconhecimento posterior servirá justamente para proporcionar resultado inverso (mais tempo perdido, menos pacificação), não se deve aplicar a figura técnica em questão. A despeito do senso comum de que as questões de ordem pública escapam à disponibilidade das partes e por isso não estão sujeitas à preclusão, parece evidente que a eventual inércia do réu em suscitar a perempção, que culmine em julgamento
} 
Revista Eletrônica de Direito Processual - REDP.

Rio de Janeiro. Ano 13. Volume 20. Número 2. Maio a Agosto de 2019

Periódico Quadrimestral da Pós-Graduação Stricto Sensu em Direito Processual da UERJ

Patrono: José Carlos Barbosa Moreira (in mem.). ISSN 1982-7636. pp. 267-312

www.redp.uerj.br

Posição esta que também comungamos, inclusive poderíamos ir mais além.

Se o magistrado verificar a possibilidade de julgamento do mérito da demanda, ainda que suscitada a perempção no processo, ele deve superar a questão e aplicar o art. 282, §2 $\mathrm{c} / \mathrm{c}$ art. $4^{\circ}$ e $5^{\circ}$, todos do CPC, como forma de privilegiar o julgamento de mérito do processo e a boa-fé processual, estabelecendo a tão desejada unidade hermenêutica do Código de Processo Civil. ${ }^{33}$

Outrossim, o que pode corroborar esse entendimento é a possibilidade de julgamento de mérito com a improcedência liminar (art. 332, do CPC), uma vez que o magistrado examina o mérito da demanda sem a presença do réu no processo. Desta forma, o mérito da demanda seria julgado independentemente da alegação ou não de perempção, não haveria interesse ao réu o julgamento sem exame do mérito gerado pela perempção.

Em que pese o julgador possa até investigar se o autor já promoveu a referida demanda três vezes, nos sistemas de automação judicial, pelo atual contexto prático do nosso Judiciário (carga excessiva de demandas), mostra-se uma hipótese bastante remota de acontecer. Além disso, os processos findos (arquivados) não se revelam tão fáceis de visualização nos sistemas eletrônicos, até para a parte interessada (réu), quiçá para os magistrados e servidores que possuem inúmeras atribuições no cotidiano.

Por fim, ainda que a decisão de mérito seja contrária ao réu, defendemos o entendimento de superação da perempção, pois assegurando todas as garantias processuais ao réu, este seria um resultado inevitável, caso a demanda se estabelecesse em qualquer das três primeiras ações.

Até porque se o direito material não falecer, e caso o réu proponha uma demanda contra o autor, este poderá alegar esse direito como matéria de defesa e, consequentemente, ser decidido o mérito em seu favor. ${ }^{34}$

do mérito da pretensão, é fator que deve ser levado em consideração com grande peso." (APRIGLIANO, Ricardo de Carvalho. Ordem Pública e Processo: o tratamento das questões de ordem pública no direito processual civil. São Paulo: Atlas, 2011, p. 143).

33 "Nos estudos sobre a interpretação constitucional, foi desenvolvido o postulado da unidade da Constituição. [...] O mesmo se aplica à interpretação do Código de Processo Civil. O Código deve ser interpretado como um conjunto de normas orgânico e coerente. Surge daí o postulado interpretativo da unidade do Código." (DIDIER JR., Fredie. Curso de Direito Processual Civil: introdução ao direito processual civil, parte geral e processo de conhecimento. Vol. 1. 19a ed. Salvador: Juspodivm, 2017, p. 171).

34 "A pretensão material do autor resta incólume: ele poderá deduzi-la como matéria de defesa, como contradireito (exceção substancial; compensação, por exemplo), caso venha a ser demandado." (DIDIER JR., Fredie. Curso de Direito Processual Civil: introdução ao direito processual civil, parte geral e processo de conhecimento. Vol. 1. 18 ed. Salvador: Juspodivm, 2016, p. 729). 
Revista Eletrônica de Direito Processual - REDP.

Rio de Janeiro. Ano 13. Volume 20. Número 2. Maio a Agosto de 2019

Periódico Quadrimestral da Pós-Graduação Stricto Sensu em Direito Processual da UERJ

Patrono: José Carlos Barbosa Moreira (in mem.). ISSN 1982-7636. pp. 267-312

www.redp.uerj.br

É de se ressaltar, por oportuno, que a obra de Ricardo Aprigliano, além de pontos que

suscitam nossos questionamentos, o que só enaltece a qualidade técnica e a importância do escrito para a doutrina brasileira, também encontram questões convergentes e que devem ser igualmente registradas aqui.

Dentre elas, merece um grande destaque a análise que o autor faz com o olhar para o futuro, apreciando temas que, à época, eram somente propostas do projeto do novo Código de Processo Civil, e que hoje fazem a realidade do Código de Processo de 2015, como a obrigatoriedade de estabelecer o contraditório e o diálogo entre as partes, mesmo em se tratando de matérias que possam ser suscitadas de ofício pelo magistrado, dentre elas as que o autor identifica como de ordem pública processual. ${ }^{35}$

Outro ponto é o esclarecimento quanto à confusão doutrinária de associar as questões que podem ser suscitadas de ofício pelos magistrados, com as questões definidas como de ordem pública processual.

Pois, como bem identifica o autor, a possibilidade destas questões serem suscitadas $e x$ officio, não implica dizer que todas as questões que o Código de Processo Civil permitir a provocação de ofício do juiz, sejam de ordem pública processual. ${ }^{36}$

A título de curiosidade, em pesquisa ao Código de Processo de 2015, constatam-se 56 expressões "de ofício" no texto normativo processual, ou seja, 56 possibilidades do magistrado, sem a provocação das partes, suscitar questões no processo, dentre as quais podemos citar a do art. 138, o qual permite o magistrado de primeiro ou de segundo grau, solicitar ou admitir de ofício amicus curiae no processo, fato este que, por si só, não impõe a esta regra jurídica a condição de norma de ordem pública processual, pois nada tem de conteúdo definido como de ordem pública, mas sim reflete o momento dogmático do processo civil contemporâneo, uma abertura para a democracia e o diálogo.

\footnotetext{
35 “Como dito acima, mesmo hoje e antes que tal dispositivo seja incorporado ao diploma processual, é inequívoco o dever do magistrado em proporcionar a manifestação prévia das partes, independentemente dos seus poderes e da possibilidade de cognição de ofício da questão. Seja como for, o legislador brasileiro acertadamente, se alinha às modernas concepções do princípio do contraditório, como ferramenta de efetiva participação das partes e legitimação de todas as decisões judiciais" (APRIGLIANO, Ricardo de Carvalho. Ordem Pública e Processo: o tratamento das questões de ordem pública no direito processual civil. São Paulo: Atlas, 2011, p. 75).

${ }^{36}$ APRIGLIANO, Ricardo de Carvalho. Ordem Pública e Processo: o tratamento das questões de ordem pública no direito processual civil. São Paulo: Atlas, 2011, p. 115.
} 
Revista Eletrônica de Direito Processual - REDP.

Rio de Janeiro. Ano 13. Volume 20. Número 2. Maio a Agosto de 2019

Periódico Quadrimestral da Pós-Graduação Stricto Sensu em Direito Processual da UERJ

Patrono: José Carlos Barbosa Moreira (in mem.). ISSN 1982-7636. pp. 267-312 www.redp.uerj.br

Desta forma, em que pese a maioria das questões processuais definidas como de ordem pública possam ser suscitadas de ofício pelo magistrado, nem todas as questões que podem ser suscitadas de ofício pelo juiz são de ordem pública.

Ademais, dissemos maioria das questões de ordem pública, pois conforme se verificou, se identificamos a possibilidade de as partes estabelecerem situações jurídicas de caráter imperativo e cogente (convenção arbitral), uma das características de exclusividade da ordem pública estatal, podemos dizer que mesmo com a rigidez (imperatividade) normativa da convenção arbitral, o Código de Processo Civil de 2015 não autorizou o conhecimento de ofício desta questão pelo magistrado (art. $485, \S 3^{\circ}, \mathrm{CPC}$ ).

Ou seja, nem toda norma de conteúdo rígido (imperativo ou cogente), pode ser conhecida de ofício pelo juiz, em que pese a convenção arbitral se trate de uma questão relacionada à incompetência absoluta do órgão estatal, sendo esta uma característica das matérias de conteúdos defendidas como de ordem pública processual pela doutrina.

Desta forma, devemos fazer uma releitura e constatar que a máxima de que toda a questão relacionada como de ordem pública processual possa ser conhecida de ofício pelo magistrado também não é correta. Pois, se identificamos uma situação jurídica que foi estabelecida pelas partes e possui uma imperatividade e cogência (marca do conteúdo de ordem pública) ao ponto de afastar o exercício da jurisdição estatal (convenção arbitral) pertinente à análise do direito material, a qual o magistrado não é autorizado a conhecer de ofício, podemos afirmar que nem toda situação de conteúdo imperativo e cogente autoriza o conhecimento de ofício pelo magistrado.

Ou seja, podemos concluir que o fato do magistrado ter a possibilidade de conhecer de questões de ofício, sem a provocação dos demais sujeitos processuais, não implica dizer que essa questão é ou não de conteúdo cogente, imperativo ou mesmo de ordem pública, somente revela uma opção legislativa em autorizar expressamente ao juiz essa forma de atuação ou não.

Assim, o sentido da expressão cognição de ofício ganha uma conotação qualificada, como forma de possibilitar um diálogo mais acurado de questões materiais ou processuais. Baliza de um processo democrático, leal, coerente, seguro e que preza pela confiança legítima. Não somente como forma de controle estatal e de justificação do poder jurisdicional, marca dos modelos e metodologias das duas primeiras codificações processuais (CPC de 1939 e CPC de 1973). 
Revista Eletrônica de Direito Processual - REDP.

Rio de Janeiro. Ano 13. Volume 20. Número 2. Maio a Agosto de 2019

Periódico Quadrimestral da Pós-Graduação Stricto Sensu em Direito Processual da UERJ

Patrono: José Carlos Barbosa Moreira (in mem.). ISSN 1982-7636. pp. 267-312

www.redp.uerj.br

Desta forma, como dito anteriormente, o fato de o texto normativo autorizar o magistrado a atuar em questões substanciais e processuais sem a provocação das partes, ou seja, "de ofício", não implica dizer que estas questões são situações de ordem pública processual.

Outro tema descrito no estudo de Ricardo Aprigliano e que, em parte, converge com o nosso entendimento é que as questões de ordem pública no processo são estabelecidas por regras jurídicas. Em que pese o autor descarte a possibilidade de uma norma princípio como de ordem pública, acreditamos que esta possa ser utilizada no plano argumentativo para a construção de uma situação de conteúdo cogente ou de ordem pública processual.

Porquanto, corroboramos do entendimento que não há aplicação direta de um princípio como de ordem pública, pois o que se constrói e se aplica é uma regra jurídica (norma de decisão) para o caso em discussão. ${ }^{37}$

Ressalte-se, por oportuno, que o próprio autor, à época, construiu uma regra jurídica utilizando o princípio do contraditório, estabelecendo que ainda sob a vigência do Código de Processo Civil de 1973, dever-se-ia respeito ao momento que o princípio do contraditório estava sendo discutido pela doutrina processual (substancial e efetivo), mesmo no caso das questões de ordem pública, construindo a regra jurídica de que o contraditório deveria ser sempre oportunizado às partes, corroborando com o normatizado atualmente nos artigos $9^{\circ}$ e 10 , do CPC. ${ }^{38}$

Assim, entendemos que, por mais que não haja uma aplicação direta de uma norma princípio de ordem pública, acreditamos que alguns princípios jurídicos carregam consigo normas que podem ser identificadas e transformadas em regras jurídicas que gerem situações jurídicas de ordem pública no processo, como no exemplo acima descrito.

Por fim, a obra de Ricardo Aprigliano, por sua qualidade científica e originalidade, mostra-se consulta obrigatória para os estudos e desdobramentos dogmáticos sobre o assunto ordem pública processual.

\footnotetext{
${ }^{37}$ NEVES, Marcelo. Entre Hidra e Hércules: princípios e regras constitucionais como diferença paradoxal do sistema jurídico. São Paulo: Martins Fontes, 2013, p. 132-137.

${ }^{38}$ APRIGLIANO, Ricardo de Carvalho. Ordem Pública e Processo: o tratamento das questões de ordem pública no direito processual civil. São Paulo: Atlas, 2011, p. 75.
} 
Revista Eletrônica de Direito Processual - REDP.

Rio de Janeiro. Ano 13. Volume 20. Número 2. Maio a Agosto de 2019

Periódico Quadrimestral da Pós-Graduação Stricto Sensu em Direito Processual da UERJ

Patrono: José Carlos Barbosa Moreira (in mem.). ISSN 1982-7636. pp. 267-312

www.redp.uerj.br

2. Proposta de sistematização das questões de ordem pública processual e substancial: Gisele Santos Fernandes Góes

Como dito no tópico anterior, a autora, Gisele Santos Fernandes Góes, desenvolveu um estudo denso sobre as questões de ordem pública no processo, em nível de doutoramento. ${ }^{39}$ Contudo, em que pese tenha iniciado o aprofundamento específico no âmbito processual brasileiro, não conhecemos a publicação do trabalho como livro, o qual tivemos a oportunidade de conhecer os escritos por cópia integral da tese, disponibilizada pela própria autora, através da mediação do caro amigo e professor, Arthur Laércio Homci, ${ }^{40}$ oportunidade que registro aos dois a minha gratidão e apreço.

Gisele Góes procura, em seu estudo, sistematizar a ordem pública no direito processual e substancial. Como a própria autora relata, a ideia de ordem pública advém de muitas questões axiológicas, o que demonstrou um estudo muito sistemático e profundo em duas esferas do direito (material e processual).

Seguindo a mesma metodologia de análise utilizada para apreciar a obra de Ricardo Aprigliano, destacaremos outros pontos, distintos desta primeira análise, mas relevantes para o artigo e que fazem parte dos nossos questionamentos sobre o assunto. São eles: a) a ordem pública aliada aos valores e à uma razão pública; b) as gradações da ordem pública (relativa e absoluta), atribuindo à prescrição como matéria de ordem pública (relativa e absoluta); e, c) a ordem pública como conceito-lógico jurídico, com reflexos jurídico-positivos.

A autora inicia e finaliza o seu estudo partindo da premissa filosófica dos valores para justificar a compreensão da ordem pública, uma vez que a ideia dos valores de proteção/blindagem que o instituto traz consigo é grande, desde o imperialismo romano até os dias atuais.

É certo que os valores (culturais, sociais, morais, religiosos, éticos etc.) são previamente destacados pela comunidade jurídica e com base neles chegam-se às normas

\footnotetext{
${ }^{39}$ GÓES, Gisele Santos Fernandes. Proposta de sistematização das questões de ordem pública processual e substancial. Tese (Doutorado). São Paulo: Pontifícia Universidade Católica, 2007.

${ }^{40}$ HOMCI, Arthur Laércio; DIAS, Jean Carlos; MOUTA, José Henrique; SILVA, Michel Ferro e. Curso de Processo Civil: processo de conhecimento. Rio de Janeiro: Lumen Juris, 2016.
} 
Revista Eletrônica de Direito Processual - REDP.

Rio de Janeiro. Ano 13. Volume 20. Número 2. Maio a Agosto de 2019

Periódico Quadrimestral da Pós-Graduação Stricto Sensu em Direito Processual da UERJ

Patrono: José Carlos Barbosa Moreira (in mem.). ISSN 1982-7636. pp. 267-312

www.redp.uerj.br

jurídicas. ${ }^{41}$ Ademais, no discurso jurídico, as normas jurídicas exteriorizam e igualmente expressam valores. ${ }^{42}$

Contudo, em que pese a densa justificação filosófica realizada por Gisele Góes, não nos parece adequado alicerçar a categoria dos valores à compreensão de ordem pública, pois não se justifica juridicamente a aplicação de valores em si, em seu sentido axiológico, mas sim de normas jurídicas. Ou seja, o que baliza o ordenamento jurídico são normas e não valores em si, em que pese estes valores possivelmente tenham contribuído para a formação das normas jurídicas e do ordenamento jurídico. ${ }^{43}$

Desta forma, dissentimos da autora neste ponto, porque ao nos debruçarmos sobre o estudo de Gisele Góes, parece-nos que o valor axiológico descrito como ordem pública está em um plano fora do mundo jurídico. Assim, acreditamos que a ideia de ordem pública deve ser justificada no mundo jurídico, não como um valor ou conjunto de valores de determinada sociedade, em que pese determinados valores possam se apresentar nos costumes sociais, e estes possam ser considerados até para a construção de normas jurídicas, como disciplina o art. $4^{\circ}$ da LINDB. ${ }^{44}$

\footnotetext{
41 "Como procuramos deixar claro, a norma jurídica constitui um modelo de conduta estabelecido pela comunidade jurídica, como resultado da valoração dos fatos da vida, com a finalidade de obter a adaptação do homem à convivência social harmônica." (MELLO, Marcos Bernardes de. Teoria do Fato Jurídico: plano da existência. $15^{\text {a }}$ ed. São Paulo: Saraiva, 2008, p. 14).

42 "Podemos, pois, dizer que o discurso da norma, enquanto estrutura dialógica, tem por função sintomática característica expressar valores, e por função de sinal despertar uma reação partidária contravalorativa, donde a função estimativa que determina o objeto da discussão como um dubium (conflitivo) eminentemente axiológico.” (FERRAZ JR., Tercio Sampaio. Direito, retórica e comunicação: subsídios para uma pragmática do discurso jurídico. $3^{\text {a }}$ ed. São Paulo: Atlas, 2015, p. 149-150).

43 "Valores não são normas. As normas têm caráter deontológico, enquanto os valores ostentam caráter axiológico. Ao passo que as normas podem ser reduzidas a um conceito deôntico básico, que é o de dever ou dever-ser, os valores reduzem-se ao conceito de bom. Os valores que eventualmente norteiam o sistema jurídico só têm significado prático se forem incorporados seletivamente a normas jurídicas, transformando-se a complexidade indeterminada (valorativa) em complexidade determinada (programada). A utilização no art. $1^{\circ}$ do CPC, do termo 'valores' não é boa, pois poderia dar margem a decisionismos, fragilizando a autonomia do direito e facilitando o solipsismo judicial. Na verdade, o processo civil será ordenado, disciplinado e interpretado conforme as normas fundamentais estabelecidas na Constituição da República. Tais normas já incorporam os valores que são caros ao sistema brasileiro. O processo civil e, de resto, as decisões judiciais não devem basear-se em 'valores', mas em 'normas'. Não é sem razão, aliás, que o art. $8^{\circ}$ do CPC determina que o juiz deve observar a legalidade, que há de ser entendida como juridicidade, ou seja, deve o juiz observar todo o ordenamento jurídico, mais propriamente as normas que o compõem." (CUNHA, Leonardo Carneiro da. In Comentários ao Código de Processo Civil. Organizadores: Lenio Luiz Streck, Dierle Nunes, Leonardo Carneiro da Cunha. São Paulo: Saraiva, 2016, p. 28-29).

44 “Art. 4 Quando a lei for omissa, o juiz decidirá o caso de acordo com a analogia, os costumes e os princípios gerais de direito."
} 
Revista Eletrônica de Direito Processual - REDP.

Rio de Janeiro. Ano 13. Volume 20. Número 2. Maio a Agosto de 2019

Periódico Quadrimestral da Pós-Graduação Stricto Sensu em Direito Processual da UERJ

Patrono: José Carlos Barbosa Moreira (in mem.). ISSN 1982-7636. pp. 267-312

www.redp.uerj.br

Principalmente no âmbito processual, os costumes devem ser compatíveis com as normas jurídicas do ordenamento, que, ${ }^{45}$ no momento contemporâneo, são representadas pelas normas constitucionais. Ademais, em regra, até os ordenamentos que tem por base os direitos costumeiros, como no caso dos anglo-americanos, exigem a confirmação dos costumes pelos precedentes judiciais, ${ }^{46}$ para que possam ser validados juridicamente. ${ }^{47}$

Assim, por mais que a Lei de Introdução às Normas do Direito Brasileiro se refira ao texto legal (lei), entendemos que o momento contemporâneo não comporta mais esta análise restrita ao texto normativo, pois a literalidade do texto só encontrava sentido quando a lei se confundia com a própria noção de Direito e balizava a atuação de forma restrita dos aplicadores do Direito. ${ }^{48}$

Atualmente, acreditamos que determinados textos normativos disciplinados por esta legislação, a exemplo do artigo supracitado, merecem uma releitura e uma reflexão maior, tendo por base o momento dogmático contemporâneo. ${ }^{49}$

Desta forma, entendemos que a compreensão deve ser de norma jurídica ao invés de lei (texto legal) do presente dispositivo, ou seja, na ausência de norma regra, utilizam-se as demais fontes de criação do direito (costumes, analogia e os princípios gerais, no plano

\footnotetext{
45 "Considerado em sua essência, assim o costume se define: A regra de conduta criada espontaneamente pela consciência comum do povo, que a observa por modo constante e uniforme e sob a convicção de corresponder a uma necessidade jurídica. Assim concebido, o costume contém em si, como elemento próprio, o sentido de sua obrigatoriedade. Mas, quando convive com o direito legislativo, o direito costumeiro só se torna efetivamente obrigatório em sendo pela lei, por modo direto ou indireto, reconhecido." (RÁO, Vicente. $\mathbf{O}$ direito e a vida dos direitos. $7^{a}$ ed. anotada e atual. São Paulo: Revista dos Tribunais, 2013, p. 271-272).

${ }^{46} \mathrm{RÁO}$, Vicente. O direito e a vida dos direitos. $7^{\mathrm{a}}$ ed. anotada e atual. São Paulo: Revista dos Tribunais, 2013, p. 270.

47 "Nada obstante, a notável distinção entre tais fontes do direito, o precedente historicamente cresceu em relevância, ainda no direito inglês do século XII, a partir da noção de que eram nas decisões judiciais que se reconheciam os costumes válidos ou vigentes. Assim, a caminhada do common law em direção aos precedentes obrigatórios foi de certa forma impulsionada pelos costumes, sobrevindo o grande aumento de importância dos precedentes e a decadência das normas costumeiras, sobretudo a partir do século XIX, com a institucionalização do stare decisis." (MACÊDO, Lucas Buril de. Precedentes Judiciais e o Direito Processual Civil. $2^{a}$ edição. revista, atualizada e ampliada. Salvador: Juspodivm, 2016, p. 83).

48 "Portanto, o primeiro passo é afastar a confusão entre texto normativo e norma. Também se pode utilizar os termos 'formulação da norma', 'disposição normativa' ou 'enunciado normativo', para distinguir a forma linguística mediante a qual uma norma se expressa no plano do direito positivo, particularmente o direito escrito.” (NEVES, Marcelo. Entre Hidra e Hércules: princípios e regras constitucionais como diferença paradoxal do sistema jurídico. São Paulo: Martins Fontes, 2013, p. 1).

49 "Exatamento por isso, ler o inciso do V do art. 966, CPC, como se apenas houvesse trocado disposição de lei por norma jurídica - ou estivesse falando de leu em sentido mais amplo - é deixar de identificar um problema teórico que nenca permitiu o uso dequadado da ação rescisória e, mais do que isso, não contribuir para o desenvoldimento do direito. Em outras palavras, a leitura adequada do inciso V do art. 966, CPC, impõe uma necessária relação entre interpretação do direito, norma jurídica e teoria dos precedentes - não por acaso igualmente encampada pelo Código de 2015". (MARINONI, Luiz Guilherme; MITIDIERO, Daniel. Ação Rescisória: do juízo rescindente ao juízo rescisório. São Paulo: Revista dos Tribunais, 2017, p. 183).
} 
Revista Eletrônica de Direito Processual - REDP.

Rio de Janeiro. Ano 13. Volume 20. Número 2. Maio a Agosto de 2019

Periódico Quadrimestral da Pós-Graduação Stricto Sensu em Direito Processual da UERJ

Patrono: José Carlos Barbosa Moreira (in mem.). ISSN 1982-7636. pp. 267-312

www.redp.uerj.br

argumentativo), o que se coaduna com o novo momento dogmático de análise dos textos normativos processuais. Inclusive podemos perceber isso quanto ao atual cabimento da ação rescisória (art. 966, V, do CPC). ${ }^{50}$

Outrossim, por essa razão, dissentimos da autora quando ela associa a compreensão de ordem pública a um ideal de razão pública, ${ }^{51}$ porque além de impor ao seu conteúdo uma carga subjetiva enorme, associa novamente a ordem pública às questões de interesse público ou coletivo, o que não nos revela salutar, como já defendemos anteriormente.

Outro ponto que nos provoca questionamentos, é a gradação da ordem pública proposta pela autora, encontrando-se este instituto em uma dinâmica dualista de absoluta e relativa.

Defende Gisele Góes que a gradação da ordem pública tem como ponto nodal a possibilidade ou não de renúncia, ou seja, as questões de ordem pública de natureza "absoluta" são irrenunciáveis, já as de natureza "relativa" comportam renúncia. ${ }^{52}$

Em que pese nossa discordância com a proposta, um ponto que nos chama atenção e se mostra relevante para os nossos questionamentos, merece destaque. Qual seja, a autora justifica a possibilidade de renúncia de uma questão de ordem pública.

No entanto, não nos parece coesa a referida classificação de peso ou força, promulgando uma noção de ordem pública mais forte e outra mais fraca, até porque existem questões que são nominadas como de ordem pública, como vimos anteriormente, além de

\footnotetext{
50 “Art. 966. A decisão de mérito, transitada em julgado, pode ser rescindida quando: [...] V - violar manifestamente norma jurídica;"

51 “O objeto da razão pública é o bem do público, esboçando-se que não é o bem público, como sinalização para o interesse estatal, mas o bem público, no rumo da coletividade. A razão pública tem três lógicas, que são: a razão dos cidadãos, como razão do público; o objeto é circunscrito ao bem do público e questões de justiça fundamental; e a sua natureza e conceito são públicos, pois determinados pelos ideais e princípios expressos pela concepção de justiça política da sociedade civil e conduzidos para todos. [...] Ora, como o foco de concentração são os interesses gerais, nada mais claro do que se dar relevância à ordem pública como razão pública, para a gestão desses interesses por meio dessa instituição. Ela é a norteadora de toda a organização da sociedade, tendo em vista que, pelo consenso e princípios de Rawls, atinge-se o equilíbrio reflexivo." (GÓES, Gisele Santos Fernandes. Proposta de sistematização das questões de ordem pública processual e substancial. Tese (Doutorado). São Paulo: Pontifícia Universidade Católica, 2007, p. 48-55).

52 “Assim, a ordem pública absoluta promove severa limitação da autonomia da autonomia da vontade, e os direitos, uma vez adquiridos, tornam-se irrenunciáveis. As situações paradigmáticas para essa ordem pública absoluta são as de conteúdo extrapatrimonial, como os direitos da personalidade, pátrio poder, ou seja, tudo que envolve os exercícios de potestades. Por outro lado, a ordem pública relativa limita a autonomia da vontade, sem a força absoluta, visto que os direitos adquiridos são passíveis de renúncia. A ilustração típica à ordem pública relativa é a de legítima dos herdeiros, que é preceito de ordem pública plenamente renunciável pela parte interessada." (GÓES, Gisele Santos Fernandes. Proposta de sistematização das questões de ordem pública processual e substancial. Tese (Doutorado). São Paulo: Pontifícia Universidade Católica, 2007, p. $65)$.
} 
Revista Eletrônica de Direito Processual - REDP.

Rio de Janeiro. Ano 13. Volume 20. Número 2. Maio a Agosto de 2019

Periódico Quadrimestral da Pós-Graduação Stricto Sensu em Direito Processual da UERJ

Patrono: José Carlos Barbosa Moreira (in mem.). ISSN 1982-7636. pp. 267-312

www.redp.uerj.br

suportarem renúncia, também são passíveis de preclusão, no caso das questões já decididas, inclusive defendido pela própria autora, ${ }^{53}$ e até podem convalidar com a coisa julgada.

Ademais, a referida gradação se mostra um pouco conflitante, pois a autora defende que a questão de ordem pública se alia à razão pública e, também, ao interesse público e coletivo. Assim, como compatibilizar essa ideia com a noção de uma ordem pública mais “fraca” (=relativa), passível de superar a razão pública, o interesse público e a coletividade.

Até entendemos que o interesse público ou a sua supremacia não devam sempre prevalecer, como tradicionalmente se defendia, principalmente em nosso contexto doutrinário contemporâneo, onde o Estado de Direito e constitucionalizado enxerga o indivíduo como cidadão, participante ativo das questões coletivas e não como mero subordinado seguidores de regras impostas. ${ }^{54}$

Outrossim, a constatação de Gisele Góes de gradações da ordem pública, além de induzir a conclusão de que não há uma única ordem pública, ao que parece, colide-se ao que a própria autora defende quanto ao conceito do instituto, atribuindo a noção à teoria geral do direito, por se tratar de um conceito lógico-jurídico.

Ou seja, como sustentar que a ordem pública é um conceito fundamental, a priori ${ }^{55}$ como defende a autora, ${ }^{56}$ e graduá-la com base nas suas consequências jurídicas, $a$ posteriori, marca dos conceitos jurídicos-positivos.

\footnotetext{
53 "Por isso, as questões de ordem pública, uma vez debatidas, precluem, não podendo haver reexame. [...], enquanto que as objeções substanciais (prescrição, decadência legal, nulidades absolutas e pagamento) são conhecidas de ofício pelo juízo de primeiro grau, e essas últimas somente podem ser reexaminadas, se for no Tribunal, desde que, no âmbito da extensão do recurso." (GÓES, Gisele Santos Fernandes. Proposta de sistematização das questões de ordem pública processual e substancial. Tese (Doutorado). São Paulo: Pontifícia Universidade Católica, 2007, p. 164).

54 "E um destes alicerces pode ser a percepção de cada pessoa de que vive sob a égide de um regime constitucional que trata a todos com o mesmo respeito e consideração; a compreensão de que não se é súdito do Estado, mas cidadão; partícipe da formação da vontade coletiva, mas também titular de uma esfera de direitos invioláveis; sujeito e não objeto da História. Só que isto requer um Estado que respeite profundamente dos interesses legítimos dos seus cidadãos." (SARMENTO, Daniel. Interesses Públicos vs. Interesses Privados na perspectiva da Teoria e da Filosofia Constitucional, p. 116-117, In SARMENTO, Daniel (org.). Interesses Públicos versus Interesses Privados: desconstruindo o princípio de Supremacia do Interesse Público. $3^{\mathrm{a}}$ tiragem. Rio de Janeiro: Lumen Juris, 2010).

55 "O conceito fundamental tem a função lógica de um a priori. É, com efeito, um esquema prévio, um ponto de vista anterior, munido do qual o pensamento se dirige à realidade, desprezando seus vários setores, fixando aquele que corresponde às linhas ideais delineadas pelo conceito. [...] Supremo ou fundamental, porquanto não é obtido de outros, nem se deixa reduzir a outros conceitos. E é anterior à experiência, uma vez que, sem a prévia determinação do conceito, não seria possível o conhecimento." (VILANOVA, Lourival. Escritos Jurídicos e Filosóficos in Sobre o conceito de direito. Vol. I. São Paulo: Axis Mundi Ibet, 2003, p. 17).

56 "Desdobrando a ordem pública, pode-se afirmar que ela não é mera criação do direito positivo, haja vista as suas múltiplas implicações, ou seja, filosóficas, da teoria geral do direito, sociológicas, enfim, tendo em vista o caráter interdisciplinar que a rodeia, ela se posta como, acima de tudo, definição lógica-jurídica." (GÓES,
} 
Revista Eletrônica de Direito Processual - REDP.

Rio de Janeiro. Ano 13. Volume 20. Número 2. Maio a Agosto de 2019

Periódico Quadrimestral da Pós-Graduação Stricto Sensu em Direito Processual da UERJ

Patrono: José Carlos Barbosa Moreira (in mem.). ISSN 1982-7636. pp. 267-312

www.redp.uerj.br

A autora não chega a um conceito da ordem pública processual e substancial, somente destaca que a ordem pública é um valor, e "como conceito lógico-jurídico está firmada pelas noções essenciais a todo e qualquer espaço estatal de interesse público e razão pública". 57

Contudo, reconhece que há uma sistematização positiva (jurídico-positiva) e destaca as suas possíveis consequências jurídicas no ordenamento, mencionando que a ordem pública como um valor encontra referência tanto nos textos normativos substanciais (Código Civil), como no processual (Código de Processo Civil).

Com base nessas premissas, Gisele Góes defende que a prescrição, por ser passível de renúncia, mostra-se uma questão substancial de ordem pública relativa, porém sustenta a autora que quanto à alteração dos prazos prescricionais, às causas suspensivas ou interruptivas, a prescrição toma feições de uma questão substancial de ordem pública absoluta.

Por isso, entendemos que o critério utilizado pela autora não se coaduna tanto com seus argumentos de base filosófica. Pois, neste caso, quem define a essência da ordem pública não é sua compreensão de valor, interesse público ou razão pública, mas o próprio texto normativo que vai disciplinar os limites e contorno das questões, marca de uma compreensão jurídico-positiva e não lógico-jurídica, como defende a autora.

Da mesma forma, a decadência também figuraria nas duas searas (absoluta e relativa), sendo a decadência legal (art. 209, CC) uma forma substancial de ordem pública absoluta e a decadência convencional (art. 211, CC) seria relativa, por se tratar de uma disposição das partes que podem suscitar em qualquer grau de jurisdição, segundo a literalidade do texto legal, porém o magistrado no processo não podia, à época, conhecer de ofício. $^{58}$

Ressalte-se que, atualmente, o art. 332, $§ 1^{\circ}$, e art. 487, II, ambos do Código de Processo Civil de 2015, autorizam o magistrado julgar a demanda com a suscitação, de

Gisele Santos Fernandes. Proposta de sistematização das questões de ordem pública processual e substancial. Tese (Doutorado). São Paulo: Pontifícia Universidade Católica, 2007, p. 153).

${ }^{57}$ GÓES, Gisele Santos Fernandes. Proposta de sistematização das questões de ordem pública processual e substancial. Tese (Doutorado). São Paulo: Pontifícia Universidade Católica, 2007, p. 153-154.

58 "Quanto à decadência, mescla-se a ordem pública, ora pela absoluta diante da decadência legal (art. 209), devendo ser verificada de ofício (art. 210 do CC), mas também pela ordem pública relativa, em função da decadência convencional (art. 211 do CC) e o magistrado não está autorizado a conhecer ex officio dela." (GÓES, Gisele Santos Fernandes. Proposta de sistematização das questões de ordem pública processual e substancial. Tese (Doutorado). São Paulo: Pontifícia Universidade Católica, 2007, p. 183). 
Revista Eletrônica de Direito Processual - REDP.

Rio de Janeiro. Ano 13. Volume 20. Número 2. Maio a Agosto de 2019

Periódico Quadrimestral da Pós-Graduação Stricto Sensu em Direito Processual da UERJ

Patrono: José Carlos Barbosa Moreira (in mem.). ISSN 1982-7636. pp. 267-312

www.redp.uerj.br

ofício, da prescrição e decadência, sem distinção de modalidades ou formas. E, por este

simples fato, alguns doutrinadores passam a enxergarem os institutos como matéria de ordem pública, ${ }^{59}$ porém sem estabelecer um critério dogmático para as suas assertivas, o que também não nos parece salutar.

E ainda há quem defenda a prescrição como matéria de ordem pública pelo fato de as partes somente poderem renunciá-la após a sua ocorrência, não podendo dispor antes de sua consumação ${ }^{60}$ - com o que também não concordamos. Pois este fundamento tem como base a ordem pública ligada à supremacia do interesse público versus o particular ${ }^{61}$ - o que dissentimos e já justificamos no primeiro tópico.

Desta forma, em que pese a gradação da ordem pública estabelecida pela autora tenha o seu inegável mérito - e possua o escopo de adequar e sistematizar a noção do instituto no contexto dogmático defendido pela autora, ao nosso entender - desnatura a própria noção defendida em sua tese quanto à ideia de ordem pública como um "valor” ligado ao interesse público e à razão pública.

De sorte que a autora não justifica como os indivíduos particularmente podem fixar normas em detrimento destes conteúdos e valores de interesse público e coletivo.

Contudo, a tese de Gisele Góes nos traz direcionamentos chaves para o desenvolvimento do nosso estudo, o qual já defendemos aqui, quanto à possibilidade de as partes estabelecerem situações de caráter cogente e imperativo, as quais podem ser utilizadas até contra os entes estatais (o império estatal). Porque, quando as partes firmam a decadência por convenção, e a convenção arbitral, criam uma situação jurídica com carga imperativa, contrapondo a ideia primeira de ordem pública, a qual só advinha do poder estatal.

\footnotetext{
59 “Conduz o dispositivo a concluir que tal assunto precede à análise de outras questões, sobretudo as de mérito propriamente dito. $\mathrm{O}$ enfrentamento é prejudicial de discussões trazidas no processo dirigidas à causa petendi, possuindo a matéria um forte caráter de ordem pública. A mesma ratio aplica-se à decadência." (RIZZARDO, Arnaldo; RZZARDO FILHO, Arnaldo; RIZZARDO, Carine Ardissone. Prescrição e Decadência. Rio de Janeiro: Forense, 2015, p. 60).

60 “A razão pela qual a prescrição não pode ser renunciada previamente decorre do fato de ser um instituto de ordem pública, independente da vontade das partes; depois de consumada, porém, é um direito, uma vantagem, um valor patrimonial, de que o indivíduo dispõe.” (CAHALI, Yussef Said. Prescrição e Decadência. $2^{\mathrm{a}}$ tir. São Paulo: Revista dos Tribunais, 2008, p. 43).

61 “Quando se diz que a prescrição é de ordem pública, tem-se em mente significar que foi estabelecida por considerações de ordem social, e não no interesse exclusivo dos indivíduos. Ela, assim, existe independentemente da vontade daqueles a quem possa prejudicar ou favorecer. A lei que a cria é rigorosamente obrigatória." (CAHALI, Yussef Said. Prescrição e Decadência. $2^{\mathrm{a}}$ tir. São Paulo: Revista dos Tribunais, 2008, p. 19-20).
} 
Revista Eletrônica de Direito Processual - REDP.

Rio de Janeiro. Ano 13. Volume 20. Número 2. Maio a Agosto de 2019

Periódico Quadrimestral da Pós-Graduação Stricto Sensu em Direito Processual da UERJ

Patrono: José Carlos Barbosa Moreira (in mem.). ISSN 1982-7636. pp. 267-312

www.redp.uerj.br

Talvez tipificar esse fenômeno de ordem pública relativa ou absoluta somente aumente as discussões e dúvidas em relação ao instituto. Por isso, estabelecer uma única compreensão ou uma nova noção do que se entende por ordem pública na contemporaneidade se faz premente.

A pesquisa de Gisele Góes, em que pese alguns pontos dissonantes com nossa compreensão, assim como a obra de Ricardo Aprigliano, mostra-se um trabalho de grande relevância doutrinária, sujeito à crítica e à reflexão, principalmente por sua densidade acadêmica e por seu pioneirismo ao tratar de tema tão espinhoso para a dogmática jurídica processual.

\section{Ordem Pública Processual: Trícia Navarro Xavier Cabral}

O estudo mais recente e específico sobre ordem pública no âmbito do processo civil é da doutora Trícia Navarro Xavier Cabral, onde enfrenta o tema, com expressivo fôlego, contribuindo bastante com o desenvolvimento da discussão. Possui como objetivo analisar o fenômeno no processo civil moderno, inclusive, segundo a autora, "repaginar a concepção tradicional, reconhecer o verdadeiro conteúdo e atualizar o tratamento da ordem pública para o processo civil contemporâneo". ${ }^{2}$

Como forma de alcançar os objetivos de sua tese, a autora inicia o estudo demarcando o momento doutrinário contemporâneo que vive o processo civil brasileiro, com as ideias marcantes do neoconstitucionalismo, e seus reflexos no Direito Processual Civil, ponto importante e que também se coaduna com a atual perspectiva dogmática. ${ }^{63}$

Como Gisele Góes, Trícia Navarro também identifica a ordem pública processual com a ideia de valores, como um "estado de coisas" ou um "estado de ordem pública" ligado às

\footnotetext{
62 "Portanto, os objetivos são: a) reformular a concepção de ordem pública e analisar a sua relação com o processo civil contemporâneo; b) identificar as questões de ordem pública processual; c) sistematizar o tratamento das questões de ordem pública processual, incluindo as suas consequências para o processo; d) verificar a aplicação das premissas da ordem pública processual a outros institutos do processo; e) analisar o assunto no direito estrangeiro; e, f) acompanhar a evolução do assunto no NCPC.” (CABRAL, Trícia Navarro Xavier. Ordem Pública Processual. Brasília: Gazeta Jurídica, 2015, p. 9).

63 " [...] a ordem constitucional contemporânea identifica-se pela irradiação dos valores fundamentais da democracia para todos os ramos do direito, na mesma medida que estes buscam a conformação de suas normas infraconstitucionais aos preceitos oriundos da Constituição, direcionando e legitimando o ordenamento jurídico brasileiro. Nesse contexto, o direito processual atua como um importante instrumento de realização dos ideais da Constituição. É por meio dele que se concretizam os direitos fundamentais constitucionalmente reconhecidos, explícita ou implicitamente, por intermédio de técnicas adequadas a tal fim." (CABRAL, Trícia Navarro Xavier. Ordem Pública Processual. Brasília: Gazeta Jurídica, 2015, p. 27).
} 
Revista Eletrônica de Direito Processual - REDP.

Rio de Janeiro. Ano 13. Volume 20. Número 2. Maio a Agosto de 2019

Periódico Quadrimestral da Pós-Graduação Stricto Sensu em Direito Processual da UERJ

Patrono: José Carlos Barbosa Moreira (in mem.). ISSN 1982-7636. pp. 267-312

www.redp.uerj.br

dimensões do interesse público, da ideia de justiça e da segurança jurídica. Destacando que

"a cláusula constitucional do devido processo legal constitui, de forma mais abrangente, os

direitos e garantias individuais e coletivas, sendo esses os instrumentos adequados para se atingir o necessário estado de ordem pública dentro do processo, conferindo, por conseguinte, a segurança jurídico-processual e o processo justo". ${ }^{64}$

Conforme já discutido no tópico anterior, ao nosso entender, não haveria necessidade de justificar um valor ou uma espécie de "razão" de ordem pública como Gisele Góes e Trícia Navarro defendem em seus estudos. De sorte que a análise do ordenamento jurídico processual impõe a apreciação de normas jurídicas e não simplesmente valores puramente axiológicos. ${ }^{65}$

Sustentar que o devido processo legal é uma forma de exteriorização ou um elemento constitucional de alcance do valor da ordem pública no processo é, ao nosso entender, elevar a noção de ordem pública à condição de uma questão que vai além do ordenamento e, na verdade, como verdadeira fonte de todo o sistema jurídico processual.

Vejamos.

É como igualá-la a ideia de uma hipótese de "norma fundamental", inicialmente defendida por Kelsen. ${ }^{66}$ Pelo menos é o que as assertivas da autora demonstram - o que não nos parece salutar.

\footnotetext{
Com efeito, a ordem pública, entendida como um estado de coisas buscado pelo direito e necessário para alcançar a segurança e confiança dos cidadãos, atua no processo como um paradigma jurídico a ser seguido, quando do controle da regularidade dos atos e procedimentos. Assim, é com o resguardo da integridade e adequação dos atos processuais que se garantirá o estado de ordem pública processual. ${ }^{67}$
}

\footnotetext{
${ }^{64}$ CABRAL, Trícia Navarro Xavier. Ordem Pública Processual. Brasília: Gazeta Jurídica, 2015, p. 99-100.

${ }^{65}$ CUNHA, Leonardo Carneiro da. In Comentários ao Código de Processo Civil. Organizadores: Lenio Luiz Streck, Dierle Nunes, Leonardo Carneiro da Cunha. São Paulo: Saraiva, 2016, p. 28-29.

66 "Um tal pressuposto, fundante da validade objetiva, será designado aqui por norma fundamental (Grundnorm). Portanto, não é do ser fático de um ato de vontade dirigido à conduta de outrem, mas é ainda e apenas de uma norma de dever-se que deflui a validade - sem sentido objetivo - da norma segundo a qual esse outrem se deve conduzir em harmonia com o sentido subjetivo do ato de vontade." (KELSEN, Hans. Teoria Pura do Direito. $8^{a}$ ed. São Paulo: Editora WMF Martins Fontes, 2009, p. 9). Ressalte-se que o próprio Kelsen, em momento posterior, retifica sua ideia quanto à norma fundamental, no sentido de que ela não é uma mera hipótese, mas sim uma ficção produzida por ato de vontade, consciente. (KELSEN, Hans. Teoria Geral das Normas. trad. José Florentino Duarte. Porto Alegre: Fabris, 1986, p. VIII e 61).

${ }^{67}$ CABRAL, Trícia Navarro Xavier. Ordem Pública Processual. Brasília: Gazeta Jurídica, 2015, p. 96.
} 
Revista Eletrônica de Direito Processual - REDP.

Rio de Janeiro. Ano 13. Volume 20. Número 2. Maio a Agosto de 2019

Periódico Quadrimestral da Pós-Graduação Stricto Sensu em Direito Processual da UERJ

Patrono: José Carlos Barbosa Moreira (in mem.). ISSN 1982-7636. pp. 267-312

www.redp.uerj.br

Em uma perspectiva pragmática, talvez não precisaríamos empreender tanta energia dogmática e recorrer a um possível ideal de ordem pública nos parâmetros estabelecidos por Trícia Navarro. Bastaria a noção histórica de um devido processo legal substancial ${ }^{68}$ ou mesmo de sua dimensão de conteúdo complexo, ${ }^{69}$ para abarcar todos os escopos e fenômenos que este "estado de ordem pública" possui no processo, conforme assevera a autora.

Por essa razão, não comungamos com essa condição eminentemente valorativa e abstrata dada à ordem pública. Pois, como se observa, não se concebe uma compreensão racional ou logicamente apreensível e sustentável.

Até porque toda norma jurídica, no fundo, reflete uma valoração fática ou cultural - o que poderia levar a conclusão de que toda norma jurídica é de ordem pública, por possuir para a sua construção carga valorativa como fundamento.

Nesse contexto, justificar-se-ia ainda mais a tese da desnecessidade de se estabelecer parâmetros jurídico-científicos ao fenômeno ordem pública e, também, acaba por a confundir com a própria vagueza e imprecisão que tem a expressão Direito. ${ }^{70}$

\footnotetext{
68 "Nesse sentido, a expressão law of the land deixa de ser apenas um princípio geral de legalidade ou de observância das leis gerais de um ordenamento, haurindo o status próprio de uma norma específica de caráter superior, traduzindo um princípio geral de constitucionalidade suprema e de contenção de poder. A Law of the Land, na linguagem que se desenvolve nos ensaios, é a norma suprema, a norma constitucional, cuja guarda e proteção se incumbe aos poderes constituídos, sobretudo os magistrados integrantes do poder judiciário." (PEREIRA, Ruitemberg Nunes. O princípio do devido processo legal substantivo. Rio de Janeiro: Renovar, 2005, p. 484).

69 "É preciso observar o contraditório e a ampla defesa (art. $5^{\circ}, \mathrm{LV}, \mathrm{CF} / 1988$ ) e dar tratamento paritário às partes do processo (art. $5^{\circ}, \mathrm{I}, \mathrm{CF} / 1988$ ); próíbem-se provas ilícitas (art. $5^{\circ}$, LVI, CF/1988); o processo há de ser público (art. 5, LX, CF/1988); garante-se o juiz natural (art. 5², XXXVII e LIII, CF/1988); as decisões hão de ser motivadas (art. 93, IX, CF/1988); o processo deve ter uma duração razoável (art. 5º, LXXVIII, CF/1988); o acesso à justiça é garantido (art. $5^{\circ}, \mathrm{XXXV}, \mathrm{CF} / 1988$ ) etc. Todas essas normas (princípios e regras) são concretizações do devido processo legal e compõem o seu conteúdo mímino. Como se vê, o devido processo legal é um direito fundamental de conteúdo complexo." (DIDIER JÚNIOR, Fredie. Curso de Direito Processual Civil: introdução ao direito processual civil, parte geral e processo de conhecimento. $18^{\mathrm{a}}$ ed. Salvador: JusPodivm, 2016, p. 68).

70 “[...] então é preciso dizer que direito é, certamente, um termo denotativa e conotativamente impreciso. Falamos, assim, em ambiguidade e vagueza semânticas. Ele é denotativamente vago porque tem muitos significados (extensão). Veja a frase: 'direito é uma ciência (1) que estuda o direito (2) quer no sentido de direito objetivo (3) - conjunto de normas -, quer no de direito subjetivo (4) - faculdades'. Ele é conotativamente ambíguo, porque, no uso comum, é impossível enunciar uniformemente as propriedades que devem estar presentes em todos os casos em que a palavra se usa. Por exemplo, se definirmos direito como um conjunto de normas, isto não cabe para direito como ciência." (FERRAZ JUNIOR, Tercio Sampaio. Introdução ao Estudo do Direito: técnica, decisão, dominação. $8^{a}$ ed. São Paulo: Atlas, 2015, p. 17).
} 
Revista Eletrônica de Direito Processual - REDP.

Rio de Janeiro. Ano 13. Volume 20. Número 2. Maio a Agosto de 2019

Periódico Quadrimestral da Pós-Graduação Stricto Sensu em Direito Processual da UERJ

Patrono: José Carlos Barbosa Moreira (in mem.). ISSN 1982-7636. pp. 267-312

www.redp.uerj.br

Pois, quando a autora afirma que "a ideia de ordem pública em um ordenamento jurídico relaciona-se com a busca e o legítimo controle estatal de valores, condutas e efeitos, gerando uma sensação de equilíbrio, harmonia e de segurança jurídica para a sociedade", ${ }^{71}$ acaba, no nosso sentir, por embaraçar e igualar ao que a dogmática defende como uma das acepções da própria noção do que é o Direito. ${ }^{72}$

É dizer, a relação entre Direito e ordem pública é de sinonímia, ou o valor ordem pública seria o próprio fundamento do Direito? Questão complexa, mas ao que parece não. Mas, por não vislumbrarmos parâmetros dogmáticos tão claros e específicos, quanto a esse ponto, poderíamos chegar a esta conclusão.

Além dessas questões iniciais, as quais também já foram discutidas nos tópicos antecedentes, como forma de objetivar a análise da obra de Trícia Navarro, destacamos os seguintes pontos que, ao nosso entender, também são relevantes para nossa análise, e merecem observações e apontamentos: a) a visão de ordem pública contemporânea e novo CPC - "princípio da prevalência da decisão de mérito"; b) compreensão de ordem pública da autora (ordem pública constitucional) e a ordem pública processual; c) identifica somente duas questões de ordem pública processual - órgão estatal investido de jurisdição e impedimento do juiz; e, d) desnecessidade de modificação terminológica do fenômeno.

A autora, tendo como norte a ideia de valores, como constatamos nas linhas iniciais deste tópico, destaca que a ordem pública processual contemporânea incorporou direitos fundamentais a sua noção, compreendendo os "valores e técnicas próprios de seu tempo, o que inclui atender ao máximo à efetividade dos direitos materiais judicializados, por meio de uma instrumentalidade adequada e da duração razoável do tempo do processo". ${ }^{73}$

Em certo ponto, retirando a categoria de valores e incluindo a noção de norma jurídica, concordamos com a autora.

\footnotetext{
${ }^{71}$ CABRAL, Trícia Navarro Xavier. Ordem Pública Processual. Brasília: Gazeta Jurídica, 2015, p. 79.

${ }^{72}$ Destacando que "os processos de adaptação social, especialmente o direito, são instrumentos indispensáveis à convivência inter-humana. [...] Daí ser imperiosa e irremovível a necessidade que tem a comunidade de manter sob controle o comportamento de seus integrantes, contendo-lhes as irracionalidades e traçando-lhes normas obrigatórias de conduta, com o sentido de estabelecer uma certa ordem capaz de obter a coexistência pacífica no meio social, com vistas à distribuição dos bens da vida.” (MELLO, Marcos Bernardes de. Teoria do Fato Jurídico: plano da existência. 15a ed. rev. São Paulo: Saraiva, 2008, p. 7).

${ }^{73}$ CABRAL, Trícia Navarro Xavier. Ordem Pública Processual. Brasília: Gazeta Jurídica, 2015, p. 82.
} 
Revista Eletrônica de Direito Processual - REDP.

Rio de Janeiro. Ano 13. Volume 20. Número 2. Maio a Agosto de 2019

Periódico Quadrimestral da Pós-Graduação Stricto Sensu em Direito Processual da UERJ

Patrono: José Carlos Barbosa Moreira (in mem.). ISSN 1982-7636. pp. 267-312

www.redp.uerj.br

Ressalte-se, por oportuno, que a autora, em um primeiro momento, literalmente, rechaça a noção de ordem pública ao caráter normativo ${ }^{74}$ - o que ao nosso entender retira a base de aplicação da ordem pública no ordenamento jurídico. Pois como aplicar, principalmente no processo civil, um "estado de coisas" que não tem caráter normativo e, ao mesmo tempo, é imprescindível à existência de qualquer sociedade civil organizada? Dando a impressão de que todos os possíveis "valores fundamentais" reconhecidos pelo ordenamento jurídico são de ordem pública, o que não parece razoável.

Nesse contexto, a autora, por conseguinte, reconhece que para que este "estado de coisas" seja obedecido, há necessidade de normatização. ${ }^{75}$ Por isso, tendo como base o próprio desdobramento feito pela autora, defendemos que não haveria necessidade de se justificar um valor ou "estado de coisas", pois o ordenamento jurídico trabalha com normas e não valores em si. Por essa razão, neste ponto, divergimos da autora.

Ademais, em que pese Trícia Navarro tenha descrito em seus objetivos que a análise contemporânea compreende a perspectiva do Novo Código de Processo Civil, ${ }^{76}$ constatamos que as análises dos fundamentos de sua tese tomam por base os textos normativos do Código de Processo Civil de 1973, ${ }^{77}$ e somente algumas passagens do texto codificado de 2015 são citadas. O que, de certa forma, frustra um pouco o leitor, pois gostaríamos de ver os posicionamentos da autora quanto às atuais diretrizes processuais. Mas, por óbvio, não retira

\footnotetext{
74 “... a ordem pública, qualificada como um estado de coisas, não possui caráter normativo e nem supra ou metalegal. Portanto, não se trata de uma regra, de um princípio, de um valor, de uma técnica e nem de uma instituição, mas sim de uma circunstância que aflora a partir do adequado funcionamento do sistema social, político e jurídico. Esse estado de coisas deve ser buscado e controlado. Destarte, a ordem pública é imprescindível à existência de qualquer sociedade civil e de qualquer modelo de Estado de Direito, já que responsável pelo equilíbrio e pela convivência harmoniosa da sociedade, por atuar como fonte de inspiração, de obediência e de controle, fazendo, pois, com que o direito tenha um papel fundamental no seu alcance". (CABRAL, Trícia Navarro Xavier. Ordem Pública Processual. Brasília: Gazeta Jurídica, 2015, p. 54).

75 "No âmbito da obediência, a ordem pública se manifesta como o eixo de segurança jurídica com força coercitiva, própria do direito, capaz de interferir e limitar os direitos fundamentais e as liberdades públicas, mediante meios adequados à paralisação de eventuais ilegalidades. São as regras de conduta impostas pelo ordenamento jurídico visando à ordem necessária à convivência em sociedade”. (CABRAL, Trícia Navarro Xavier. Ordem Pública Processual. Brasília: Gazeta Jurídica, 2015, p. 54-55).

76 "Por fim, o trabalho também acompanhará a evolução das discussões da matéria no Novo Código de Processo Civil (NCPC), sancionado como Lei n. ${ }^{\circ} 13.105$ de 16 de março de 2015”. (CABRAL, Trícia Navarro Xavier. Ordem Pública Processual. Brasília: Gazeta Jurídica, 2015, p. 9).

${ }^{77}$ Podemos identificar isto em sua obra, nas páginas: 76, 110, 119, 129, 130, 134, 135, 136, 137, 150, 152, 154, $164,165,166,169,171,172,173,175,176,177,180,181,182,183,185,186,187,188,190,195,197,200-$ 201 (análise do rito sumário, que foi revogado pelo CPC/15), 202, 203, 204, 205, 221, 225, 226, 227, 228,237 , 239, 244, 273 e 275, 276, 280, 281, 282, 285, 287, 296, 297, 298, 360 (análise do agravo retido, que foi extinto com o CPC/15), 363, 368, 373, 376, 380, 383, 384, 387, 388, 415, 416, 420, 421, 422 e 425.
} 
Revista Eletrônica de Direito Processual - REDP.

Rio de Janeiro. Ano 13. Volume 20. Número 2. Maio a Agosto de 2019

Periódico Quadrimestral da Pós-Graduação Stricto Sensu em Direito Processual da UERJ

Patrono: José Carlos Barbosa Moreira (in mem.). ISSN 1982-7636. pp. 267-312

www.redp.uerj.br

a densidade da análise realizada pela autora, uma vez que traz vários questionamentos relevantes do assunto.

Assim, talvez por não analisar alguns textos do Código de Processo Civil de 2015, a autora rebate os argumentos de Ricardo Aprigliano, ${ }^{78}$ quanto à possibilidade de um "princípio da prevalência da análise do mérito", destacando que discorda do autor pois "a pronúncia de mérito é uma consequência lógico-normativa inerente ao próprio exercício da função jurisdicional, de modo que não deve ser tratada de forma finalística, e sim como uma regra de conduta descritiva". ${ }^{79}$

Ressalte-se que a autora utiliza como teoria, para a sua compreensão de norma princípio e norma regra, a tese de Humberto Ávila. Porém, ainda que adotemos as ideias do autor, em contraponto a outras teses,${ }^{80}$ atualmente também poderíamos dizer que existe sim uma norma princípio e, também, uma norma regra (comando descritivo de conduta), quanto à prevalência da análise do mérito, bastando a exegese do art. $4^{\circ}$ do $\mathrm{CPC} .^{81}$

Por essa razão, dissentimos da autora. Porque, em que pese a sua análise tenha como norte o processo civil contemporâneo (2015), como visto, constatamos que a maioria de seu exame foi realizado com base no texto normativo revogado (1973), porquanto conforme o novo Código de Processo Civil, acima mencionado, mesmo aplicando a compreensão de princípios e regras de Humberto Ávila, ${ }^{82}$ há uma norma fundamental (art. $4^{\circ}, \mathrm{CPC}$ ) e vários outros comandos de condução do processo, no sentido determinar que o magistrado imprima o máximo de esforço para dar uma resposta de mérito (do direito) ao jurisdicionado.

Nesse ponto, conforme discutido no tópico 1., deste artigo, entendemos que Ricardo Aprigliano andou melhor que Trícia Navarro, apesar de o autor ter elaborado sua tese algum tempo antes da promulgação do Código de Processo Civil de 2015, já vislumbrava as questões processuais que atualmente foram exteriorizadas nas normas fundamentais do processo.

\footnotetext{
78 APRigliano, Ricardo de Carvalho. Ordem Pública e Processo: o tratamento das questões de ordem pública no direito processual civil. São Paulo: Atlas, 2011, p. 75 e 106.

${ }^{79}$ CABRAL, Trícia Navarro Xavier. Ordem Pública Processual. Brasília: Gazeta Jurídica, 2015, p. 82-83.

${ }^{80}$ Destaque-se que nosso entendimento quanto aos princípios e regras tem como base a teoria de Robert Alexy e Marcelos Neves, ambos em: ALEXY, Robert. Teoria dos Direitos Fundamentais. trad. Virgílio Afonso da Silva. São Paulo: Malheiros, 2008; NEVES, Marcelo. Entre Hidra e Hércules: princípios e regras constitucionais como diferença paradoxal do sistema jurídico. São Paulo: Martins Fontes, 2013.

81 "Art. 4ำ As partes têm o direito de obter em prazo razoável a solução integral do mérito, incluída a atividade satisfativa."

${ }_{82}$ ÁVILA, Humberto. Teoria dos Princípios: da definição à aplicação dos princípios jurídicos. $10^{\mathrm{a}}$ edição, ampliada e atualizada. São Paulo: Malheiros, 2009, p. 78-79.
} 
Revista Eletrônica de Direito Processual - REDP.

Rio de Janeiro. Ano 13. Volume 20. Número 2. Maio a Agosto de 2019

Periódico Quadrimestral da Pós-Graduação Stricto Sensu em Direito Processual da UERJ

Patrono: José Carlos Barbosa Moreira (in mem.). ISSN 1982-7636. pp. 267-312

www.redp.uerj.br

Quanto à compreensão da autora sobre ordem pública e ordem pública processual, destaca que atualmente, por influência do momento dogmático contemporâneo do neoconstitucionalismo, na verdade há uma "ordem pública constitucional", ${ }^{83}$ o que, em parte, concordamos.

Porquanto, como a autora trabalha esta ideia de "estado de coisas de ordem pública", fica difícil visualizar este sentimento no ordenamento jurídico constitucional. Assim, ao nosso sentir, talvez seria mais pragmático enxergar uma rigidez ou cogência nas próprias normas constitucionais, despiciendo justificar uma espécie de "valor" de ordem pública constitucional, uma vez que já existem normas jurídicas constitucionais que o exteriorizam, seja de forma geral e/ou imperativa, tendo como espoco a proteção, a tutela de questões sociais e dos próprios cidadãos.

Nesse contexto, a autora conceitua ordem pública processual

[...] como o estado de coisas que representa a observância e o controle de garantias constitucionais e processuais, por meio de técnicas processuais formadas por diferentes níveis de interesses públicos e que são responsáveis pela regularidade processual, no alcance da tutela jurisdicional adequada justa e efetiva, e que equacionam, por conseguinte, os valores da segurança jurídica e da efetividade no desenvolvimento do processo. ${ }^{84}$

Como podemos perceber, a autora, com seu conceito, dá uma elasticidade quanto à compreensão de ordem pública no âmbito processual. De sorte que, associar essa noção a uma gradação de níveis de interesse público no controle de garantias constitucionais e processuais, torna bastante volátil e difícil de identificar claramente estas questões no processo civil contemporâneo.

\footnotetext{
83 “....a ordem pública pode ser conceituada como sendo um estado de coisa fundamental à estabilização das relações humanas e que imprime a sensação de segurança e de controle das relações sociais pelo Estado, por meio de regras de obediência que devem ser observadas por todos, sendo, pois, imprescindível à legitimidade e à legitimação do poder estatal. Como se vê, a ordem pública que qualifica esse estado de coisas possui conteúdo constitucional. Com efeito, e ordem pública constitui um conceito jurídico indeterminado cuja noção vem sendo construída a partir da evolução constitucional e suas decorrentes implicações legais, doutrinárias e jurisprudenciais. Trata-se, pois, de cláusula geral em branco, delimitada por uma interpretação constitucional e justificada de forma objetiva e razoável. Pode-se falar, inclusive, de uma ordem pública constitucional". (CABRAL, Trícia Navarro Xavier. Ordem Pública Processual. Brasília: Gazeta Jurídica, 2015, p. 52-53).

${ }^{84}$ CABRAL, Trícia Navarro Xavier. Ordem Pública Processual. Brasília: Gazeta Jurídica, 2015, p. 118.
} 
Revista Eletrônica de Direito Processual - REDP.

Rio de Janeiro. Ano 13. Volume 20. Número 2. Maio a Agosto de 2019

Periódico Quadrimestral da Pós-Graduação Stricto Sensu em Direito Processual da UERJ

Patrono: José Carlos Barbosa Moreira (in mem.). ISSN 1982-7636. pp. 267-312

www.redp.uerj.br

Destarte, qualquer norma processual que tenha o escopo de controlar uma garantia constitucional, por exemplo o contraditório, a ampla defesa e o devido processo legal, por ter lugares comuns com o interesse público, podem ser considerados de conteúdo da ordem pública processual, ou de um "estado de coisas de ordem pública". E, segundo a própria autora, as questões de ordem pública processual são indisponíveis; ${ }^{85}$ por conseguinte, não podendo ser renunciadas e não admitem preclusão - o que não acontece com estas situações, o qual tem a possibilidade de não ser exercido (forma de renúncia tácita) ou simplesmente ser exercido extemporaneamente (preclusão temporal).

Partindo desta compreensão de ordem pública processual, a autora, analisando o que a doutrina processual comumente alude como questões de ordem pública no processo (requisitos/admissibilidade da ação e dos recursos, pressupostos processuais e nulidades), rechaça tal divisão - o que concordamos, tomando como base doutrina contemporânea sobre o assunto, ${ }^{86}$ asseverando que estas questões podem ser reconhecidas exclusivamente como pressupostos processuais, os quais são divididos "em três categorias preponderantes de valores: de interesse público absoluto, de interesse público relativo e de interesse privado". 87

Desta forma, Trícia Navarro, para identificar quais são as questões de ordem pública no processo, apresenta em sua tese, três modalidades de pressupostos processuais, os reconhecidos como questões de ordem pública processual, com indisponibilidade total dos sujeitos processuais, em outro grupo estariam nas questões de interesse público, podendo sofrer alguma superação e, por último, as questões disponíveis, as quais possuem um grau elevado de disponibilidade das partes. ${ }^{88}$

\footnotetext{
85 "Algumas questões processuais são dotadas de elevado grau de interesse público, visando à proteção do Estado ou das partes. Por isso, se tornam absolutamente indisponíveis pelos sujeitos, merecendo um tratamento diferenciado. Podem ser consideradas as verdadeiras questões de ordem pública, justificando todos os graves efeitos processuais daí inerentes, como o conhecimento de ofício pelo juiz, a qualquer tempo, podendo ensejar desde o indeferimento da inicial, até a extinção do feito sem resolução do mérito, bem como a declaração de nulidade absoluta, sem possibilidade de superação". (CABRAL, Trícia Navarro Xavier. Ordem Pública Processual. Brasília: Gazeta Jurídica, 2015, p. 162).

86 DIDIER JR., Fredie. Pressupostos processuais e condições da ação: o juízo de admissibilidade do processo. São Paulo: Saraiva, 2005, p. 100.

87 CABRAL, Trícia Navarro Xavier. Ordem Pública Processual. Brasília: Gazeta Jurídica, 2015, p. 161.

88 "Dessa forma, os pressupostos processuais podem ser divididos em três espécies distintas: a) questões de ordem pública, cujas hipóteses são taxativas, em que impera um grau elevado de interesse público na proteção do Estado ou sujeitos processuais, ensejando a indisponibilidade processual; b) questões de interesse público, que podem ser superadas de acordo com a dinâmica da política legislativa ou judiciária; c) questões disponíveis, que em sua maioria atuam em benefício das partes e que podem ser superadas diante do grau de disponibilidade
} 
Revista Eletrônica de Direito Processual - REDP.

Rio de Janeiro. Ano 13. Volume 20. Número 2. Maio a Agosto de 2019

Periódico Quadrimestral da Pós-Graduação Stricto Sensu em Direito Processual da UERJ

Patrono: José Carlos Barbosa Moreira (in mem.). ISSN 1982-7636. pp. 267-312

www.redp.uerj.br

Nesse contexto, a autora, depois de enfrentar várias questões, que identificou de forma

geral como pressupostos processuais, constata a existência somente duas questões no processo com aspectos da compreensão de ordem pública processual, são elas: a) a existência de órgão estatal investido de jurisdição; e, b) as questões quanto ao impedimento do juiz. Assim, para Trícia Navarro, estas são as questões que são insuperáveis (inderrogáveis), absolutamente indisponíveis (irrenunciáveis ou não passíveis de autocomposição), podem ser arguidas a qualquer tempo (não precluem). ${ }^{89}$

Assim, ressalta a autora como questão de ordem pública processual que um ato jurisdicional seja praticado por um magistrado investido na jurisdição e em seu regular exercício, sob pena de o ato processual praticado sem estes dois pressupostos processuais possuir um vício insanável, que sequer convalida com o trânsito em julgado, mesmo após o prazo da ação rescisória. ${ }^{90}$

Assim, discordamos desta posição dada pela autora por dois pontos, vejamos.

Primeiramente, partimos da premissa de que os atos jurisdicionais praticados no processo judicial sem a existência de órgão investido na jurisdição sequer passam pelo plano da existência, são inexistentes ${ }^{91}$ — o que não se coaduna com a premissa da autora de que estes atos estão no plano da validade e seriam nulos. Podendo, inclusive, ser impugnados

processual”. (CABRAL, Trícia Navarro Xavier. Ordem Pública Processual. Brasília: Gazeta Jurídica, 2015, p. 161).

89 "Podem ser consideradas as verdadeiras questões de ordem pública, justificando todos os graves efeitos processuais daí inerentes, como o conhecimento de ofício pelo juiz, a qualquer tempo, podendo ensejar desde o indeferimento da inicial, atpe a extinção do feito sem resolução de mérito, bem como a declaração de nulidade absoluta, sem possibilidade de superação". (CABRAL, Trícia Navarro Xavier. Ordem Pública Processual. Brasília: Gazeta Jurídica, 2015, p. 162).

90 "Trata-se, pois, de requisito indispensável ao processo, que nem o Estado e nem as partes podem dispor, de modo a afastar qualquer tentativa de superação. Ressalte-se, por fim, que esse requisito é considerado por parte da doutrina como pressuposto de existência do processo, uma vez que o processo se inicia com a propositura da demanda dirigida a um órgão estatal investido de jurisdição, de modo que o ajuizamento de uma petição inicial a órgão sem essa qualidade não faria nascer uma relação jurídica processual. Embora a tese sobre a inexistência de ato processual não seja aceita neste trabalho, especialmente porque, por mais grave que seja o vício, ele possui o potencial de produzir efeitos, a falta de órgão estatal investido de jurisdição é tão grave que não se convalida nem mesmo com o advento da coisa julgada, sendo possível a declaração de nulidade inclusive após o decurso do prazo para a interposição de rescisória". (CABRAL, Trícia Navarro Xavier. Ordem Pública Processual. Brasília: Gazeta Jurídica, 2015, p. 163-164).

91 "A investidura na função jurisdicional é pressuposto de existência do processo e dos atos jurídicos processuais do juiz (decisões, despachos, colheita de provas etc.). considerar-se-á inexistente o processo se a demanda for ajuizada perante não-juiz e decisão prolatada por não-juiz é uma não-decisão, é apenas um simulacro a que não se pode emprestar qualquer eficácia jurídica". (DIDIER JR, Fredie. Curso de Direito Processual Civil: introdução ao direito processual civil, parte geral e processo de conhecimento. 18 ed. Salvador: Juspodivm, 2016, p. 318). 
Revista Eletrônica de Direito Processual - REDP.

Rio de Janeiro. Ano 13. Volume 20. Número 2. Maio a Agosto de 2019

Periódico Quadrimestral da Pós-Graduação Stricto Sensu em Direito Processual da UERJ

Patrono: José Carlos Barbosa Moreira (in mem.). ISSN 1982-7636. pp. 267-312

www.redp.uerj.br

por ação anulatória a qualquer tempo. Assim, por questão de premissa dogmática, dissentimos quanto ao primeiro ponto.

Segundo, a autora afirma que inexistência de órgão investido na jurisdição estatal é uma questão indisponível às partes e insuperável. Contudo, sabemos que as partes podem, em comum acordo, renunciar a jurisdição estatal e eleger um árbitro através da convenção arbitral, como já verificamos aqui nas primeiras linhas do nosso estudo.

Desta forma, as partes, quando firmam a convenção arbitral, renunciam, quanto ao mérito a ser apreciado pelo árbitro, ao direito fundamental de inafastabilidade do controle jurisdicional, ou seja, renunciam à jurisdição estatal, tornando o órgão investido na jurisdição absolutamente incompetente. ${ }^{92}$

Nesse sentido, Carmona ${ }^{93}$ destaca que a convenção arbitral, "como pacto processual, seus objetivos são os de derrogar a jurisdição estatal, submetendo as partes à jurisdição dos árbitros".

Ademais, ressalte-se que o Código de Processo Civil de 1973 já previa, em seu art. 475-N, IV, e o atual (CPC), em seu art. 515, VII, continua dispondo que a sentença arbitral é um título executivo judicial. Ou seja, todos os planos jurídicos (existência, validade e eficácia) da sentença proferida pelo juiz togado se apresentam na sentença proferida pelo árbitro, um ato proferido fora do âmbito do órgão de jurisdição estatal. Inclusive, por conta dessa determinação legal, há uma discussão sobre a compreensão da jurisdição na contemporaneidade, se o árbitro exerce ou não jurisdição. ${ }^{94}$

Por estas questões, dissentimos da autora, uma vez que se constata que há uma parcela de disposição das partes quanto à submissão da discussão ao órgão jurisdicional, de sorte

\footnotetext{
92 “[...] 3. Lei de Arbitragem (L. 9.307/96): constitucionalidade, em tese, do juízo arbitral; discussão incidental da constitucionalidade de vários dos tópicos da nova lei, especialmente acerca da compatibilidade, ou não, entre a execução judicial específica para a solução de futuros conflitos da cláusula compromissória e a garantia constitucional da universalidade da jurisdição do Poder Judiciário (CF, art. $5^{\circ}$, XXXV). Constitucionalidade declarada pelo plenário, considerando o Tribunal, por maioria de votos, que a manifestação de vontade da parte na cláusula compromissória, quando da celebração do contrato, e a permissão legal dada ao juiz para que substitua a vontade da parte recalcitrante em firmar o compromisso não ofendem o artigo $5^{\circ}$, XXXV, da CF.[...] (STF - SE 5206 AgR, Relator(a): Min. SEPÚLVEDA PERTENCE, Tribunal Pleno, julgado em 12/12/2001, DJ 30-04-2004 PP-00029 EMENT VOL-02149-06 PP-00958).

${ }^{93}$ CARMONA, Carlos Alberto. Arbitragem e Processo: um comentário à Lei n. ${ }^{\circ}$ 9.307/96. $3^{\mathrm{a}}$ ed. rev., atual. e ampl. São Paulo: Atlas, 2009, p. 79.

${ }_{94}$ Ressalte-se que no Fórum Permanente de Processo Civil, em que pese cancelados, dois enunciados confirmavam o exercício de jurisdição pelo árbitro: Enunciado 1. O árbitro é dotado de jurisdição para processar e julgar a controvérsia a ele apresentada, na forma da lei; e, Enunciado 3. O árbitro é juiz de fato e de direito e como tal exerce jurisdição sempre que investido nessa condição, nos termos da lei. Porém, ambos foram cancelados no III FPPC-Rio.
} 
Revista Eletrônica de Direito Processual - REDP.

Rio de Janeiro. Ano 13. Volume 20. Número 2. Maio a Agosto de 2019

Periódico Quadrimestral da Pós-Graduação Stricto Sensu em Direito Processual da UERJ

Patrono: José Carlos Barbosa Moreira (in mem.). ISSN 1982-7636. pp. 267-312

www.redp.uerj.br

que as partes podem renunciar o referido direito fundamental inserido no art. $5^{\circ}, \mathrm{XXXV}, \mathrm{CF}$, o que, pragmaticamente, impõe uma nova dogmática da defendida pelos autores, no sentido de que o conteúdo da ordem pública no processo civil é intransponível e inderrogável.

Outrossim, quanto ao impedimento do magistrado, não há como identificar esse conteúdo intransponível, insuperável ou inderrogável, caso em que, segundo a autora, o qualificaria como uma questão de ordem pública processual, senão vejamos.

Em que pese o impedimento do magistrado seja um dos fundamentos mais essenciais do processo, inclusive é uma das hipóteses de cabimento da ação rescisória (art. 966, II, CPC), pois interfere objetivamente na imparcialidade do juiz, pode ser regularizado no processo, não ensejando o julgamento sem exame do mérito (art. 485, CPC).

Assim, extrai-se do texto processual que o substituto legal atua no processo enquanto

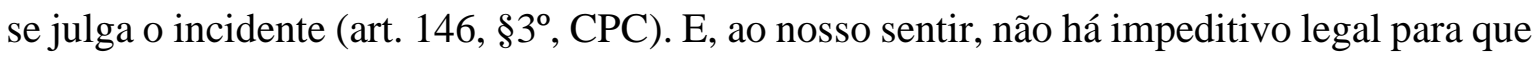
o juiz substituto mantenha ou ratifique o posicionamento proferido nos atos decisórios do magistrado impedido, aplicando analogicamente o art. $64, \S 4^{\circ}$, do $\mathrm{CPC},{ }^{95}$ que trata da incompetência absoluta que também, juntamente com o impedimento do magistrado, é uma hipótese de cabimento da ação rescisória, inclusive no mesmo inciso. ${ }^{96}$

Desta forma, as matérias elencadas no art. 966, do CPC, autorizam o juízo rescindente, é dizer, a possibilidade de quebra da coisa julgada para que a questão seja apreciada e, caso interfira no resultado antes consolidado, modifique o que foi anteriormente decidido. ${ }^{97}$

Ademais, no âmbito recursal, caso seja suscitado no recurso o impedimento do magistrado que proferiu a decisão judicial recorrida, ao nosso sentir, nada impede que o Tribunal aplique sistematicamente o procedimento do art. $1.013, \S 3^{\circ}$, do CPC,${ }^{98}$ superando a questão da nulidade do ato judicial (impedimento) e proferindo outro em sua substituição

\footnotetext{
95 “Art. 64. A incompetência, absoluta ou relativa, será alegada como questão preliminar de contestação. [...] $\S 4$ - Salvo decisão judicial em sentido contrário, conservar-se-ão os efeitos de decisão proferida pelo juízo incompetente até que outra seja proferida, se for o caso, pelo juízo competente.”.

96 "Art. 966. A decisão de mérito, transitada em julgado, pode ser rescindida quando: [...] II - for proferida por juiz impedido ou por juízo absolutamente incompetente;".

$97 \quad$ "A sentença é impugnável pela ação rescisória quando a infração, que era sanável, não se apagou. Mas aí estamos em terreno tautológico: se a infração era sanável e não se apagou, então foi a lei que determinou isso, permitindo, na espécie, a ação rescisória”. (MIRANDA, Pontes de. Comentários ao Código de Processo Civil. Tomo VI (arts. 476-495). São Paulo: Forense, 1975, p. 256).

98 “Art. 1.013. A apelação devolverá ao tribunal o conhecimento da matéria impugnada. [...] $\$ 3$ o Se o processo estiver em condições de imediato julgamento, o tribunal deve decidir desde logo o mérito quando: I - reformar sentença fundada no art. 485; II - decretar a nulidade da sentença por não ser ela congruente com os limites do pedido ou da causa de pedir; III - constatar a omissão no exame de um dos pedidos, hipótese em que poderá julgá-lo; IV - decretar a nulidade de sentença por falta de fundamentação.”
} 
Revista Eletrônica de Direito Processual - REDP.

Rio de Janeiro. Ano 13. Volume 20. Número 2. Maio a Agosto de 2019

Periódico Quadrimestral da Pós-Graduação Stricto Sensu em Direito Processual da UERJ

Patrono: José Carlos Barbosa Moreira (in mem.). ISSN 1982-7636. pp. 267-312

www.redp.uerj.br

(art. 1.008, CPC), inclusive confirmando ou não a decisão judicial recorrida, aplicando-se também, sistematicamente, o procedimento do art. $64, \S 4^{\circ}$, do CPC.

Ressalte-se, ainda, que, escoado o prazo da ação rescisória, o sistema processual, para fins de segurança jurídica, estabilidade e coerência, admite a convalidação dos vícios do ato processual decisório que transitou em julgado, não comportando qualquer outro meio de impugnação de rescindibilidade.

Contudo, o sistema processual admite que na impugnação à execução no cumprimento de sentença, a parte possa alegar um vício que ultrapassa a rescindibilidade e permanece aceso, como no caso da inexistência ou nulidade de citação no processo de conhecimento (art. 525, $\S 1^{\circ}$, I, e art. 535, I, no caso da Fazenda Pública, ambos do CPC), ${ }^{99}$ ou através da ação anulatória autônoma - o que somente tem o condão de anular todos os atos processuais até o momento em que a parte deveria ser citada, para que este ato aconteça validamente e o processo siga o seu normal trâmite.

Vale dizer, contrariando o que normalmente se diz, ao nosso sentir, não é uma questão insanável; pelo contrário, mostra-se uma questão sanável a qualquer tempo, é possível a sua correção a qualquer momento, inclusive após o trânsito em julgado.

Por tudo isso, durante o desenvolvimento do estudo, não conseguimos encontrar um respaldo dogmático que sustente como conteúdo essencial da ordem pública no processo civil, a questão insanável ou inderrogável, como defende a autora e os autores antecedentes.

Desta forma, resta-nos constatar que há uma necessidade premente de uma nova dogmática da ordem pública no processo civil. Porque, nos moldes que os doutrinadores vêm defendendo a compreensão deste fenômeno, podemos concluir que no processo civil não existe este "estado de coisas" insanável, inderrogável e indisponível, quiçá não tenha existido da forma apreendida e passada pela doutrina.

“Art. 525. Transcorrido o prazo previsto no art. 523 sem o pagamento voluntário, inicia-se o prazo de 15 (quinze) dias para que o executado, independentemente de penhora ou nova intimação, apresente, nos próprios autos, sua impugnação. $§ 1$ 을 $\mathrm{Na}$ impugnação, o executado poderá alegar: I - falta ou nulidade da citação se, na fase de conhecimento, o processo correu à revelia; / Art. 535. A Fazenda Pública será intimada na pessoa de seu representante judicial, por carga, remessa ou meio eletrônico, para, querendo, no prazo de 30 (trinta) dias e nos próprios autos, impugnar a execução, podendo arguir: I - falta ou nulidade da citação se, na fase de conhecimento, o processo correu à revelia;”. 
Revista Eletrônica de Direito Processual - REDP.

Rio de Janeiro. Ano 13. Volume 20. Número 2. Maio a Agosto de 2019

Periódico Quadrimestral da Pós-Graduação Stricto Sensu em Direito Processual da UERJ

Patrono: José Carlos Barbosa Moreira (in mem.). ISSN 1982-7636. pp. 267-312

www.redp.uerj.br

Outrossim, identificamos uma dissonância na obra de Trícia Navarro, quando da sua

análise dos requisitos de admissibilidade dos recursos especial e extraordinário, destacando a autora que são questões de ordem pública processual ${ }^{100}$ — o que se mostra contrário à sua conclusão e à própria noção de ordem pública proposta por ela. Pois há possibilidade de disposição das partes e mesmo correção dos requisitos de forma geral (art. 932, parágrafo único, do CPC), ${ }^{101}$ inclusive especificamente no âmbito dos Tribunais Superiores (art. 1.032 e art. 1.033 , do $\mathrm{CPC})^{102}$ — o que foi constatado pela própria autora. ${ }^{103}$ Assim, não há de se falar em ordem pública processual destes requisitos de admissibilidade, nos termos defendidos pela autora.

Por essa razão, ao contrário do que constata Trícia Navarro, ${ }^{104}$ defendemos que se faz necessária uma possível redefinição terminológica do que se deve compreender por ordem pública no processo civil brasileiro, sendo esta uma proposição deste artigo.

Como inicialmente descrito, é importante frisar que o estudo de Trícia Navarro contribui bastante com estudo do tema, pois traça questões relevantíssimas quanto à necessidade de uma nova dogmática da ordem pública processual, bem como faz uma análise

100 "Denota-se, pois, que a interposição de recurso especial ou extraordinário demanda, além do atendimento dos requisitos de admissibilidade gerais, o cumprimento de certas exigências específicas para o seu conhecimento, ensejando um filtro recursal bem mais complexo, que se tem chamado de jurisprudência defensiva. De qualquer modo, os requisitos de admissibilidade são considerados questões de ordem pública, autorizando o seu conhecimento de ofício pelo magistrado". (CABRAL, Trícia Navarro Xavier. Ordem Pública Processual. Brasília: Gazeta Jurídica, 2015, p. 393).

101 "Art. 932. Incumbe ao relator: [...] Parágrafo único. Antes de considerar inadmissível o recurso, o relator concederá o prazo de 5 (cinco) dias ao recorrente para que seja sanado vício ou complementada a documentação exigível".

102 "Art. 1.032. Se o relator, no Superior Tribunal de Justiça, entender que o recurso especial versa sobre questão constitucional, deverá conceder prazo de 15 (quinze) dias para que o recorrente demonstre a existência de repercussão geral e se manifeste sobre a questão constitucional. / Art. 1.033. Se o Supremo Tribunal Federal considerar como reflexa a ofensa à Constituição afirmada no recurso extraordinário, por pressupor a revisão da interpretação de lei federal ou de tratado, remetê-lo-á ao Superior Tribunal de Justiça para julgamento como recurso especial".

103 "Ademais, pelo novo Código, o relator do recurso especial, caso entendesse se tratar de questão constitucional, estaria autorizado a aplicar a fungibilidade recursal, concedendo prazo para que o recorrente adequasse às exigências do recurso extraordinário, o que, se cumprido, enseja a remessa do recurso ao STF. Do mesmo modo, se um recurso extraordinário o relator considerar que o caso envolve a revisão de lei federal ou de tratado e apenas como reflexa a ofensa à Constituição, também poderá remetê-lo ao STJ para processamento e julgamento". (CABRAL, Trícia Navarro Xavier. Ordem Pública Processual. Brasília: Gazeta Jurídica, 2015, p. 394).

104 “Quanto à denominação - 'questões de ordem pública' -, não se mostra producente discutir ou tentar estabelecer outro título para uma cultura processual já consolidada. Poder-se-ia até, por exemplo, sugerir que as hipóteses fossem tratadas como 'questões de interesse público', 'questões de ordem' ou outro rótulo similar, mas seria gastar energia científica com aspectos superficiais do tema”. (CABRAL, Trícia Navarro Xavier.

Ordem Pública Processual. Brasília: Gazeta Jurídica, 2015, p. 126). 
Revista Eletrônica de Direito Processual - REDP.

Rio de Janeiro. Ano 13. Volume 20. Número 2. Maio a Agosto de 2019

Periódico Quadrimestral da Pós-Graduação Stricto Sensu em Direito Processual da UERJ

Patrono: José Carlos Barbosa Moreira (in mem.). ISSN 1982-7636. pp. 267-312

www.redp.uerj.br

bastante importante da doutrina processual estrangeira. ${ }^{105}$ No entanto, em que pese a publicação de sua tese tenha ocorrido em 2015, a análise do sistema processual português foi realizada tendo como base o CPC de 1961 e não o novo CPC português de 2013.

Portanto, como bem ressalta Trícia Navarro, a compreensão da ordem pública processual contemporânea, tem que servir à segurança jurídica, à confiança e ao processo justo, sendo processo justo o que possibilita às partes regularizarem, superarem os vícios processuais, para que se dê oportunidade de se discutir analiticamente o direito debatido na demanda. Talvez este seja o verdadeiro objetivo das normas processuais.

\section{A insuficiência do parâmetro da ordem pública: Antonio do Passo Cabral}

O autor, em sua tese de livre-docência, escreve um tópico dedicado à ordem pública, ao tratar dos possíveis critérios de limitação das convenções processuais. ${ }^{106} \mathrm{Em}$ que pese não seja um estudo específico sobre as questões de ordem pública no processo civil, como vimos até o momento, merece a nossa análise pela qualidade de informações e provocações sobre a expressão ordem pública de uma forma geral, realizando um instigante contraponto aos institutos basilares da dinâmica processual contemporânea.

O tópico da tese de Antonio Cabral intitulado "a insuficiência do parâmetro da 'ordem pública'", ${ }^{107}$ ao rechaçar a ordem pública e suas derivações como forma de limitação das convenções processuais, acaba por dar uma grande contribuição ao tema, pois traz vários questionamentos às matérias que envolvem a temática da ordem pública.

Além de todas as questões que já discutimos até aqui, como a problemática da ligação do conteúdo de ordem pública ao de interesse público e Direito Público, a possibilidade de preclusão, renúncia, convalidação, convenção e sanação das questões ditas de ordem pública etc., um dos apontamentos relevantes que o autor nos apresenta, e que é um dos objetivos desta artigo, é a proposição, em um estudo oportunamente mais aprofundado, também dos pressupostos processuais com a possibilidade de convenção, ${ }^{108}$ renúncia e sanação, em

\footnotetext{
${ }^{105}$ CABRAL, Trícia Navarro Xavier. Ordem Pública Processual. Brasília: Gazeta Jurídica, 2015, p. 313-353. 106 CABRAL, Antonio do Passo. Convenções Processuais. Salvador: Juspodivm, 2016.

107 CABRAL, Antonio do Passo. Convenções Processuais. Salvador: Juspodivm, 2016, 306.

108 "Não é viável genericamente afirmar que questões referentes aos pressupostos processuais não podem ser objeto de acordo. Trata-se de um raciocínio ainda fruto da concepção hiperpublicista de que todas ou a maior parte das normas processuais são inderrogáveis, decorrendo daí que a ordem pública eliminaria a
} 
Revista Eletrônica de Direito Processual - REDP.

Rio de Janeiro. Ano 13. Volume 20. Número 2. Maio a Agosto de 2019

Periódico Quadrimestral da Pós-Graduação Stricto Sensu em Direito Processual da UERJ

Patrono: José Carlos Barbosa Moreira (in mem.). ISSN 1982-7636. pp. 267-312

www.redp.uerj.br

contraponto ao que parte da doutrina processual tradicional vem defendendo, como podemos

verificar na análise das obras de Ricardo Aprigliano, Gisele Góes e Trícia Navarro.

Contudo, ressalte-se que o total descrédito do autor em relação aos conteúdos de ordem pública apresentados atualmente pela doutrina faz com que, em sua tese, abandone por completo estas compreensões como um possível critério de limitação dos negócios jurídicos processuais, o que, de certa forma, mostra-se justificável devido à celeuma dogmática que gira em torno do assunto, mas não nos parece salutar.

O que somente fortalece e justifica o objetivo deste artigo, ao promover uma discussão propositiva de uma nova dogmática da compreensão de ordem pública no processo civil contemporâneo.

No nosso entender, os institutos devem ser aprimorados, remodelados e não totalmente descartados. Assim, estudar este fenômeno e estabelecer uma estrutura dogmática contemporânea mais clara de seus conteúdos, talvez minimize este discurso de total abandono da compreensão de ordem pública no processo civil, ainda que se quebre o paradigma ordem pública e se estabeleça outra terminologia e compreensão deste fenômeno.

Até porque o próprio autor constata e admite a limitação de convenção processual advinda de regras jurídicas processuais, o qual denomina como limitações derivadas de "reserva de lei". ${ }^{109} \mathrm{O}$ que, ao nosso entender, pode ser extraído dos conteúdos denominados de cogente e imperativo, com um olhar contemporâneo das normas constitucionais ${ }^{110}$ e como forma de garantir a segurança jurídica e, consequentemente, a estabilidade, coerência e integridade do ordenamento jurídico processual.

autonomia da vontade.” (CABRAL, Antonio do Passo. Convenções Processuais. Salvador: Juspodivm, 2016, p. 313).

109 "Um primeiro limite à convencionalidade são hipóteses em que o ordenamento estabelece reserva de lei para a norma processual. Nestes espaços, a vontade das partes não lhes autoriza, por acordo, criar uma regra que pudesse derrogar a norma legal. Assim, por exemplo seria inválida convenção para criar recurso não previsto em lei, porque a previsão de tipos recursais deve estar prevista em regra legal. Também não seria possível alterar o cabimento dos recursos (ampliar o rol do art. 1.015 do CPC para as decisões interlocutórias agraváveis ou afirmar que alguma daquelas decisões seria apelável)." (CABRAL, Antonio do Passo. Convenções Processuais. Salvador: Juspodivm, 2016, p. 316).

110 "Este é o primeiro CPC editado sob a vigência da $\mathrm{CF} / 88$, inserindo-se no contexto do Estado Constitucional, que é, a um só tempo, Estado de direito e Estado democrático. O Estado de direito impõe observância aos princípios da legalidade, isonomia e segurança jurídica. O Estado democrático funda-se na liberdade e na participação. Esses são os fundamentos do CPC, que justificam várias normas nele contidas." (CUNHA, Leonardo Carneiro da. In Comentários ao Código de Processo Civil. Organizadores: Lenio Luiz Streck, Dierle Nunes, Leonardo Carneiro da Cunha. São Paulo: Saraiva, 2016, p. 28). 
Revista Eletrônica de Direito Processual - REDP.

Rio de Janeiro. Ano 13. Volume 20. Número 2. Maio a Agosto de 2019

Periódico Quadrimestral da Pós-Graduação Stricto Sensu em Direito Processual da UERJ

Patrono: José Carlos Barbosa Moreira (in mem.). ISSN 1982-7636. pp. 267-312

www.redp.uerj.br

Desta forma, se as partes não podem estabelecer novos recursos além do que a norma processual comina taxativamente (art. 994, do CPC), somente mostra que estas regras possuem uma margem de rigidez e imperatividade não afeta a convenção das partes.

Assim, de certa forma, encontra um lugar comum às percepções de ordem pública, em que pese elas possam renunciar ao direito de interpor os recursos previstos ou até mesmo convencionar os prazos recursais (art. 190, do CPC).

Então, há normas de conteúdo rígido e que geram situações jurídicas agudas, no sentido de quebra do desenvolvimento hígido ou regular do processo. Porém, não se coadunam com a compreensão dogmática de ordem pública quanto à total indisponibilidade, à inderrogabilidade e à insanabilidade.

Por este motivo, faz-se premente deixar mais clara a estrutura dogmática do que se entende como conteúdo de ordem pública no processo civil brasileiro da contemporaneidade, e não simplesmente descartar esta compreensão jurídica tão antiga e, em certa medida, necessária ao ordenamento jurídico.

\section{Considerações finais: Será a ordem pública processual uma situação de "tû-tû"?}

Como visto, a doutrina processual de vanguarda ${ }^{111}$ e a contemporânea brasileira, ao associar a ideia de ordem pública a valores abstratos, como "vontade coletiva", "estado de coisas", "razão pública", "transcendentes às esferas individuais", talvez acabe por identificar a ordem pública processual com uma situação de "tû-tû", descrita por Alf Ross. ${ }^{112}$

111 "Ordem pública é o conjunto de valores, princípio e normas transcendentes às esferas individuais de
direitos, cuja observância interessa à sociedade como um todo ou às instituições do Estado, que a corporifica
(interest rei publicae). Normas cujo conteúdo diga respeito à preservação desses valores são, por essa mesma
razão, dotadas de imperatividade absoluta, ou seja, são cogentes". (DINAMARCO, Cândido Rangel.
Instituições de Direito Processual Civil. Vol. I. 8 a ed. rev. e atual. São Paulo: Malheiros, 2016, p. 137-138).
112
mais primitivos hoje existentes no mundo. Sua civilização foi recentemente descrita pelo antropólogo Ilírio
Meugnin, de cujo relato foi extraído o que segue. Essa tribo, de acordo com Meugnin, acredita que se um
determinado tabu é violado - por exemplo, se um homem encontra-se com sua sogra, ou se mata um animal
totêmico, ou se alguém ingere alimento preparado pelo chefe - surge o que é denominado 'tû-tû'. Os membros
da tribo dizem, ademais, que quem comete a infração se investe de 'tû-tû'. É muito difícil explicar o que
significa isso. Talvez o mais próximo de uma explicação seja dizer que 'tû-tû' é concebido como uma espécie
de força ou estigma perigoso que recai sobre o culpado e ameaça toda a comunidade com o desastre. Por esse
motivo, uma pessoa que esteja em 'tû-tû' tem que ser submetida a uma cerimônia especial de purificação. É
óbvio que a tribo Aisat-naf vive na mais obscura superstição. 'Tû-tû' não é nada, supõe-se, ou uma palavra
desprovida de qualquer significado. As situações anteriormente mencionadas de violação do tabu decerto dão
origem a diversos efeitos naturais, tais como o sentimento de terror, porém, evidentemente, não são esses
fenômenos, nem algum outro demonstrável, o que se designa com a expressão 'tû-tû'. O discurso acerca de 
Revista Eletrônica de Direito Processual - REDP.

Rio de Janeiro. Ano 13. Volume 20. Número 2. Maio a Agosto de 2019

Periódico Quadrimestral da Pós-Graduação Stricto Sensu em Direito Processual da UERJ

Patrono: José Carlos Barbosa Moreira (in mem.). ISSN 1982-7636. pp. 267-312

www.redp.uerj.br

Uma expressão que não comporta significado específico, ou melhor, uma expressão que pode servir para fundamentar várias suposições e hipóteses, encontrando-se em um campo da mera imaginação, da ilusão de quem a aplica, podendo, inclusive, produzir vários resultados distintos, bastando a vontade do sujeito (intérprete) para isso.

Justificamos e explicamos.

Em nada muda quanto às suas consequências jurídico-processuais, se dissermos ou não que o impedimento do juiz, por exemplo, seria uma questão de ordem pública processual que pode, em determinado momento, ser apreciada de ofício e a qualquer tempo (caso não tenha sido apreciada, não estará sujeito à preclusão); pode gerar nulidade do ato decisório (caso não seja ratificada pelo juízo competente); é uma hipótese de cabimento da ação rescisória (art. 966, II, do CPC); e, pode ocorrer a convalidação com o trânsito em julgado (caso ultrapasse o prazo da ação rescisória, não comportando mais qualquer medida processual).

Assim, percebemos que, independentemente de gravarmos o impedimento do magistrado como sendo um "tû-tû" processual (ordem pública processual) ou não, estes serão os possíveis acontecimentos e consequências jurídicas admitidas pelo sistema processual contemporâneo. É dizer, se mudarmos a expressão ordem pública e dissermos que o impedimento do magistrado deixa o processo em uma situação de "tû-tû", nada muda, tanto teoricamente como pragmaticamente, e as consequências jurídicas ocorrerão, independente do título ou nomenclatura que se dê a este fenômeno processual do impedimento do juiz.

Ademais, por todas estas consequências admitidas pelo sistema processual, não se mostraria adequado o entendimento doutrinário de que a ordem pública é insuperável, intransmissível e indisponível, quiçá nunca tenha sido, mas nós começamos a nos darmos conta disso agora.

Por essa razão, constata-se que essa expansão conceitual e a carga argumentativa da expressão ordem pública, na verdade, somente encontra guarida e aplicação do ponto de vista jurídico, quando associada às situações jurídicas geradas por determinadas normas jurídicas. Caso não seja assim, com a devida deferência aos estudos históricos e dogmáticos realizados sobre o assunto, a ordem pública somente fique para a história como uma coisa

'tû-tû' é puramente destituído de sentido". (ROSS, Alf. Tû-Tû. trad. Edson L. M. Bini. São Paulo: Quartier Latin, 2004, p. 13-15). 
Revista Eletrônica de Direito Processual - REDP.

Rio de Janeiro. Ano 13. Volume 20. Número 2. Maio a Agosto de 2019

Periódico Quadrimestral da Pós-Graduação Stricto Sensu em Direito Processual da UERJ

Patrono: José Carlos Barbosa Moreira (in mem.). ISSN 1982-7636. pp. 267-312

www.redp.uerj.br

que aterrorizou os juristas, mas nunca se soube o que é, e se realmente existe ou se é uma mera suposição mental.

Por exemplo, no Direito Internacional, quando não se aplica uma norma estrangeira por violação à ordem pública, na verdade, o intérprete está identificando que há uma norma jurídica interna contrária ou de conteúdo diverso da norma alienígena que se pretende aplicar no ordenamento jurídico pátrio. Pois a antinomia ou violação se dá em face das normas jurídicas postas em um ordenamento e não em face de um ideal axiológico e metafísico que eu possa intitular de "tû-tû", "estado de coisas", "razão pública", "transcendentes às esferas individuais" ou "ordem pública processual".

No processo civil brasileiro, parece-nos que a doutrina vem identificando um comando normativo e atribuindo a ele o título de "tû-tû" processual (questão de ordem pública processual), a maioria das vezes por refletir determinados vícios relevantes ao regular e válido andamento processual (órgão investido de jurisdição; impedimentos do magistrado; ilegitimidade; interesse; ausência de citação; nulidades etc.), sem se questionar da necessidade ou não de tal titulação e como adequar dogmaticamente as assertivas quanto à irrenunciabilidade e inderrogabilidade.

Desta forma, em que pese, em certos casos, o estigma do "tû-tû" ou da ordem pública possa ser suprimido, para não gerar comportamentos irracionais e ideológicos, como bem identifica Alf Ross ao discutir a ideia de direito subjetivo, ${ }^{113}$ em outros casos possa se mostrar pragmaticamente necessária, no sentido de que em determinada atuação exista uma possível violação ou desordem no sistema jurídico, como uma espécie de senso comum. ${ }^{114}$

Nesse contexto, talvez a terminologia do tipo "tû-tû" (ordem pública) ainda se faça útil ao ordenamento jurídico contemporâneo, seja porque possua uma referência semântica, ${ }^{115}$

113 ROSS, Alf. Tû-Tû. trad. Edson L. M. Bini. São Paulo: Quartier Latin, 2004, p. 18 e 28.

114 "Nos escritos clássicos latinos, essa expressão tem o significado de costume, gosto, modo comum de viver ou de falar. Nesse sentido, Cícero adverte que no orador é falta grave 'abominar o gênero vulgar do discurso e o costume do senso comum' (De or., I, 3, 12; cf. 2, 16, 68), e Sêneca afirma que 'a filosofia visa a desenvolver o senso comum' (Ep., 5, 4; cf. 105, 3). Vico expressava numa fórmula lapidar o pensamento tradicional dos autores latinos ao afirmar: 'O senso comum é um juízo sem reflexão, comumente sentido por uma ordem, todo um povo, toda uma nação, ou por todo o gênero humano’ (Ciência nova, 1744, Dignidade 12), e ao atribuir ao senso comum a função de confirmar e determinar 'o arbítrio humano, incertíssimo por sua própria natureza, [...] no que diz respeito às necessidades ou utilidades humanas' (ibid., Dignidade 11)”. (ABBAGNANO, Nicola. Dicionário de filosofia. Tradução da $1^{a}$ edição brasileira coordenada e revista por Alfredo Bosi; revisão da tradução e tradução dos novos textos Ivone Castilho Benedetti. $6^{a}$ ed. São Paulo: Editora WMF Martins Fontes, 2012, p. 1.038).

115 "Todavia, o que é notável, conforme o relato de Meugnin, é que parece que essa palavra, a despeito de sua carência de significado, possui uma função a ser cumprida na linguagem cotidiana do povo. Os 
Revista Eletrônica de Direito Processual - REDP.

Rio de Janeiro. Ano 13. Volume 20. Número 2. Maio a Agosto de 2019

Periódico Quadrimestral da Pós-Graduação Stricto Sensu em Direito Processual da UERJ

Patrono: José Carlos Barbosa Moreira (in mem.). ISSN 1982-7636. pp. 267-312

www.redp.uerj.br

ainda que não possua um determinado significado, seja por sua historicidade ou pela ligação de seu conteúdo com a noção de que existem certos limites de atuação dos sujeitos participantes do processo civil, inclusive dos entes estatais.

Ademais, não se pretende aqui, com este singelo artigo, abolir a expressão ordem pública do ordenamento pátrio, justificando-se em certa medida sua permanência por também ser aplicada popularmente (senso comum) com a referência semântica de ordem jurídica (conjunto de normas jurídicas), ordem social, paz social, soberania estatal etc., devendo o interlocutor, ao exprimir a referida expressão, identificar em que sentido está utilizando a ideia de ordem pública, sob pena de cair em tautologia, como vem se mostrando a doutrina processual civil contemporânea.

Desta forma, o escopo principal desta análise é o de proposição, no sentido da simplificação, revigoramento e adequação sistemática do que a doutrina vem sustentando como matérias de ordem pública no âmbito processual, estabelecendo uma nova dogmática de sua estruturação, enquadrando-a ao novo momento constitucional do processo civil brasileiro; do contrário, a ordem pública processual, essa desconhecida, ${ }^{116}$ "em si não significa nem mais nem menos que "tû-tû"”. 117

\section{REFERÊNCIAS}

APRigliano, Ricardo de Carvalho. Ordem Pública e Processo: o tratamento das questões de ordem pública no direito processual civil. São Paulo: Atlas, 2011. AZEVEDO NETO, João Luiz Lessa de. Arbitragem e Poder Judiciário: a definição da competência do árbitro. Salvador: Juspodivm, 2016.

\footnotetext{
enunciados que incluem a palavra 'tû-tû' se afiguram capazes de preencher as duas principais funções de toda linguagem: prescrever e descrever, ou, para ser mais explícito, expressar ordens ou regras e fazer afirmações sobre fatos. Se digo, em três idiomas diferentes, 'meu pai morreu', 'Mein Vater ist gestorben' e 'Mon père est mort', temos três frases diferentes, mas uma única afirmação. Apesar de suas diferentes formas linguísticas, as três frases referem-se a um único e mesmo estado de coisas (o fato de que meu pai morreu), e este estado de coisas é afirmado como existente na realidade, diferentemente de algo meramente imaginado. $\mathrm{O}$ estado de coisas ao qual uma frase se refere chama-se 'referência semântica'. Pode ser definido, com maior precisão, como o estado de coisas que se relaciona de tal modo com a afirmação que, se supusermos que o primeiro efetivamente existe, então consideramos ser verdadeira a segunda. A referência semântica de uma proposição dependerá dos usos linguísticos que prevalecem na comunidade". (ROSS, Alf. Tû-Tû. trad. Edson L. M. Bini. São Paulo: Quartier Latin, 2004, p. 15-16)

116 Parafraseando o aposto utilizado por Fredie Didier Jr., em DIDIER JR., Fredie. Sobre a Teoria Geral do Processo, essa desconhecida. Salvador: Juspodivm, 2012.

117 ROSS, Alf. Tû-Tû. trad. Edson L. M. Bini. São Paulo: Quartier Latin, 2004, p. 54.
} 
Revista Eletrônica de Direito Processual - REDP.

Rio de Janeiro. Ano 13. Volume 20. Número 2. Maio a Agosto de 2019

Periódico Quadrimestral da Pós-Graduação Stricto Sensu em Direito Processual da UERJ

Patrono: José Carlos Barbosa Moreira (in mem.). ISSN 1982-7636. pp. 267-312 www.redp.uerj.br

BARBOSA MOREIRA, José Carlos. Convenções das partes sobre matéria processual. In Revista de Processo. Vol. 33/1984, Jan-Mar/1984, p. 182-191.

O novo processo civil brasileiro: exposição sistemática do procedimento. $23^{\mathrm{a}}$ ed. rev. e atual. Rio de Janeiro: Forense, 2005.

CABRAL, Antonio do Passo. Convenções Processuais. Salvador: Juspodivm, 2016.

CABRAL, Trícia Navarro Xavier. Ordem Pública Processual. Brasília: Gazeta Jurídica, 2015.

CARMONA, Carlos Alberto. Arbitragem e Processo: um comentário à Lei n. ${ }^{\circ}$ 9.307/96. $3^{\text {a }}$ ed. rev. atual. e ampl. São Paulo: Atlas, 2009.

CHARPENEL, Yves. L'ordre public judiciaire: La laque et le vernis. Collection Ordre Public. Paris: Economica, 2014.

CUNHA, Leonardo Carneiro da. A Fazenda Pública em Juízo. 14ª ed. rev., atual e ampl. Rio de Janeiro: Forense, 2017.

O Processo Civil no Estado Constitucional e os Fundamentos do Projeto do Novo Código de Processo Civil Brasileiro. Revista de Processo. Ano 37. vol. 209. Julho, 2012.

DIDIER JR., Fredie. Pressupostos processuais e condições da ação: o juízo de admissibilidade do processo. São Paulo: Saraiva, 2005.

. Sobre a Teoria Geral do Processo, essa desconhecida. Salvador: Juspodivm, 2012.

DINAMARCO, Cândido Rangel. Instituições de Direito Processual Civil. Vol. I. $8^{\text {a ed. }}$ rev. e atual. São Paulo: Malheiros, 2016.

A Instrumentalidade do Processo. $15^{\mathrm{a}}$ ed. revista e atualizada. São Paulo: Malheiros, 2013.

.; LOPES, Bruno Vasconcelos Carrilho. Teoria Geral do novo Processo Civil. São

Paulo: Malheiros, 2016.

DUBREUIL, Charles-André (Direction). L'ordre Public. (Actes du colloque organisé les

15 \& 16 décembre 2011 par le Centre Michel de I'Hospital de I'Université d'Auvergne (Clermont I). Paris: Éditions Cujas, 2013.

FERRAZ JUNIOR, Tercio Sampaio. Introdução ao Estudo do Direito: técnica, decisão, dominação. $8^{a}$ ed. São Paulo: Atlas, 2015. 
Revista Eletrônica de Direito Processual - REDP.

Rio de Janeiro. Ano 13. Volume 20. Número 2. Maio a Agosto de 2019

Periódico Quadrimestral da Pós-Graduação Stricto Sensu em Direito Processual da UERJ

Patrono: José Carlos Barbosa Moreira (in mem.). ISSN 1982-7636. pp. 267-312 www.redp.uerj.br

_. Direito, retórica e comunicação: subsídios para uma pragmática do discurso jurídico. $3^{\text {a }}$ ed. São Paulo: Atlas, 2015.

GÓES, Gisele Santos Fernandes. Proposta de sistematização das questões de ordem pública processual e substancial. Tese (Doutorado). São Paulo: Pontifícia Universidade Católica, 2007.

KUHN, Thomas S. A estrutura das revoluções científicas. trad. Beatriz Vianna Boeira e Nelson Boeira. 12a ed. São Paulo: Perspectiva, 2013.

VILANOVA, Lourival. Escritos Jurídicos e Filosóficos in Sobre o conceito de direito. Vol. I. São Paulo: Axis Mundi Ibet, 2003. 